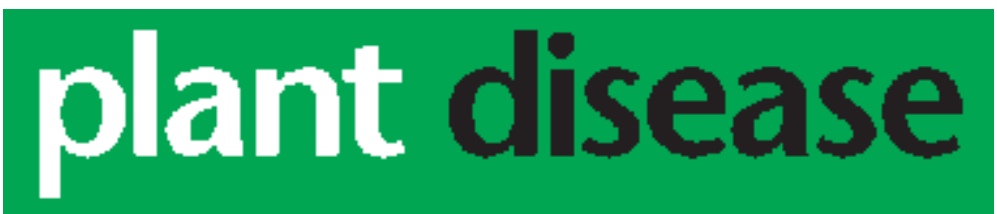

\title{
LAMP Detection and Identification of the Blackleg Pathogen Leptosphaeria biglobosa 'brassicae'
}

\begin{tabular}{|r|l|}
\hline Journal: & Plant Disease \\
\hline Manuscript ID & PDIS-08-20-1819-RE.R1 \\
\hline Danuscript Type: & Research \\
\hline Author: & 09-Jan-2021 \\
\hline Complete List of Authors: & $\begin{array}{l}\text { Du, Ran; Huazhong Agricultural University, Plant Protection } \\
\text { Huang, Yongju; University of Hertfordshire School of Life and Medical } \\
\text { Sciences, Biological and Environmental Sciences } \\
\text { Zhang, Jing; Huazhong Agricultural University, Plant Pathology } \\
\text { Yang, Long; Huazhong Agricultural University, Plant Pathology } \\
\text { Wu, Mingde; Huazhong Agricultural University, Plant Pathology } \\
\text { Li, Guoqing; Huazhong Agricultural University, Plant Protection; } \\
\text { Huazhong Agricultural University, }\end{array}$ \\
\hline Keywords: & $\begin{array}{l}\text { Fungi < Causal Agent, oilseeds and legumes < Field crops < Crop Type, } \\
\text { Pathogen detection < Subject Areas }\end{array}$ \\
\hline &
\end{tabular}

\section{SCHOLARONE Manuscripts}


LAMP Detection and Identification of the Blackleg Pathogen Leptosphaeria biglobosa 'brassicae'

\section{3}

4 Ran Du, State Key Laboratory of Agricultural Microbiology, Huazhong Agricultural

5 University, Wuhan 430070, China; Y. J. Huang, School of Life and Medical Sciences,

6 University of Hertfordshire, AL10 9, Hatfield, AB, UK; Jing Zhang, Long Yang, Mingde

7 Wu, and Guoqing Li, State Key Laboratory of Agricultural Microbiology, Huazhong

8 Agricultural University, Wuhan 430070, China

$9 \quad$ Correspondence: Dr. G. Q. Li, E-mail: guoqingli@mail.hzau.edu.cn 


\section{Abstract}

Blackleg of oilseed rape is a damaging invasive disease caused by the species complex Leptosphaeria maculans $(\mathrm{Lm}) /$ L. biglobosa $(\mathrm{Lb})$, which are composed of at least two and seven phylogenetic subclades, respectively. Generally, Lm is more virulent than Lb, however, under certain conditions, Lb can cause a significant yield loss in oilseed rape. Lb 'brassicae' (Lbb) has been found to be the causal agent for blackleg of oilseed rape in China, whereas Lm and Lb 'canadensis' (Lbc) were frequently detected in imported seeds of oilseed rape, posing a risk of spread into China. In order to monitor the blackleg-pathogen populations, a diagnostic tool based on loop-mediated isothermal amplification (LAMP) was developed using a 615-bp-long DNA sequence from Lbb that was derived from a randomly amplified polymorphic DNA assay. The LAMP was optimized for temperature and time, and tested for specificity and sensitivity using the DNA extracted from Lbb, Lbc, Lm, and 10 other fungi. The results showed that the optimal temperature and time were $65^{\circ} \mathrm{C}$ and $40 \mathrm{~min}$, respectively. The LAMP primer set was specific to Lbb and highly sensitive as it detected the Lbb DNA as low as 132 fg per reaction. The LAMP assay was validated using the DNA extracted from mycelia and conidia of a well-characterized Lbb isolate, and its utility was evaluated using the DNA extracted from leaves, stems, pods and seeds of oilseed rape. The LAMP assay developed herein will help for monitoring populations of the blackleg pathogens in China and developing strategies for management of the blackleg disease. 
Blackleg (phoma stem canker) of oilseed rape (Brassica napus) is a world-wide economically important disease (Piening et al. 1975; Gugel and Petrie 1992; Laing 1986;

Salisbury et al. 1995; Dilmaghani et al. 2000; West et al. 2000; Fitt et al. 2006; Lob et al. 2013; Molina et al. 2017). It is caused by two closely related and morphologically similar ascomycetous fungi, Leptosphaeria maculans (anamorph: Plenodomus lingam) and Leptosphaeria biglobosa (anamorph: Plenodomus biglobosus), which form a species complex (Mendes-Pereira et al. 2003). Both fungi can infect leaves, stems and pods of oilseed rape, causing phoma leaf spots, phoma stem cankers and phoma pod spots, respectively (Fitt et al. 2006b). Among these symptoms, phoma stem canker is the most important regarding seed yield loss, as it can cause stem collapse (lodging), thereby reducing seed production.

Numerous studies indicated that L. maculans is more virulent than L. biglobosa in terms of the extent of damage to the plants and seed production, as L. maculans can invade into the vascular tissue of the basal stem, where it may cause stem collapse, in contrast, L. biglobosa usually infects the epidermal tissue of the upper stem, where it rarely causes stem collapse (Plummer et al. 1994; Williams and Fitt 1999; West et al. 2001; Fitt et al. 2006a). Previous studies showed that the L. maculans/L. biglobosa species complex (especially L. maculans) is responsible for serious economic losses to the industry of oilseed rape (or canola) in Australia, Canada, France, Germany and UK since the 1970s. It was estimated that the blackleg disease of oilseed rape caused an average annual economic loss of US\$167 million during 1983 to 1998 in Alberta of Canada, and US\$70 million during 2000 to 2002 in the UK (Fitt et al. 2006b, 2008).

In China, blackleg of oilseed rape was first reported in the early 2000s, and the pathogen for that disease was identified as NA1 or B-group of L. maculans (West et al. 2000), which was later re-classified as L. biglobosa (Shoemaker and Brun, 2001). Large-scale field surveys demonstrated that this disease widely occurred in oilseed rape-plantation areas (Li et al. 
2013). Compared to healthy plants, diseased plants had less yield with the average single-plant seed yield loss ranging from $10 \%$ to $56 \%$ (Rong et al. 2015; Cai et al. 2018). So far, only L. biglobosa has been found in oilseed rape and cruciferous vegetables in China (Fitt et al. 2008; Li et al. 2013; Liu et al. 2014; Zhang et al. 2014; Cai et al. 2015, 2018), and L. maculans was thus officially considered as a quarantine pathogen since the late 2000s (Zhou et al. 2010; Wang et al. 2011).

Both L. maculans and L. biglobosa can be further classified into subclades or subspecies based on phylogenetic analysis of the nucleotide sequences of the internal transcribed spacer region of ribosomal DNA (ITS-rDNA), and a few nuclear genes such as the mating type gene MAT1-2 and the genes coding for actin and $\beta$-tubulin (Mendes-Pereira et al. 2003). So far, two subclades have been identified in L. maculans, including 'brassicae' on Brassica and 'lepidii' on Lepidium sp. (Mendes-Pereira et al. 2003). Seven subclades have been identified in L. biglobosa, including 'americensis', 'australensis', 'brassicae', 'canadensis' and 'occiaustralensis' on Brassica spp., 'erysimii' on Erysimum, and 'thlaspii' on Thlaspi sp. (Voigt et al. 2005; Vincenot et al. 2008; Zou et al. 2019). Among these L. biglobosa subclades, 'brassicae' and 'canadensis' are the most common and important, L. biglobosa 'brassicae' has been found in the continents of America, Asia and Europe (Fitt et al. 2006a; Vincenot et al. 2008; Dilmaghani et al. 2009; Liu et al. 2014), and L. biglobosa 'canadensis' has been detected in the continent of America (Canada, USA) as well as in Australia (van de Wouw et al. 2008; Dilmaghani et al. 2009; Liu et al. 2014). Five other subcluades of $L$. biglobosa, including 'americensis', 'australensis', 'erysimii', 'occiaustralensis' and 'thlaspii' are the minor subclades, 'americensis' was only found in USA (Zou et al. 2019), 'erysimii' was found in Canada (Voigt et al. 2005), 'australensis' and 'occiaustralensis' were found in Australia (Vincenot et al. 2008).

It is well recognized that L. maculans and L. biglobosa can be spread over a long 
distance through international trade of seeds of oilseed rape and/or exchange of germplasm resources of cruciferous crops (Chigogora and Hall 1995; Wang et al. 2003; Chen et al. 2010; Zhou et al. 2010; Wang et al. 2011; Chen et al. 2013). Therefore, detection and identification of L. maculans and L. biglobosa in crop seeds is essential in preventing spread of these two pathogens into other regions. Since the late 1970s, the deep-freezing blotter method has been recommended by the International Seed Testing Association (ISTA) to detect L. maculans and L. biglobosa in contaminated or infected seeds of cruciferous crops, including oilseed rape (Limonard 1968). The key point in that method is inhibition of seed germination under freezing temperatures (e.g. $-20^{\circ} \mathrm{C}$ ) and the subsequent promotion of growth of the seedborne fungi on the seeds under normal temperatures (e.g. $20^{\circ} \mathrm{C}$ ) (Wang et al. 2003).

Moreover, monitoring of the populations of L. maculans and L. biglobosa in fields planted with oilseed rape and cruciferous vegetables is also important regarding management of the blackleg disease (West et al. 2001; Dilmaghani et al. 2009). L. maculans and L. biglobosa usually produce similar symptoms on stems with formation of abundant black pycnidia (West et al. 2001; Li et al. 2013). Therefore, it is difficult to distinguish these two pathogens just based on disease symptoms and location of infection (e.g. basal and upper stems) and the disease symptoms. Many researchers have made efforts to develop simple, rapid and accurate methods to detect and identify L. maculans and L. biglobosa on diseased plant tissues. The methods so far developed include plant assays (e.g. virulence tests), morphological characterization (e.g. colony growth, pseudothecial shape, ascospore germlings), metabolite profiling (e.g. pigments, phytotoxins), typing of glucose phosphate isomerase, karyotyping, serological typing, DNA analyses (e.g. RFLP, RAPD, PCR) and genome analyses (Williams and Fitt, 1999; Mendes-Pereira et al., 2003; Liu et al., 2006; van de Wouw et al., 2008. Vincenot et al. 2008; Grandaubert et al. 2014). However, these methods are usually time-consuming, labor-intensive and/or dependent on special expertise 
and instruments. There is a need to develop simpler, faster and more convenient methods for detection and identification of these two pathogens.

Since the early 2000s, loop-mediated isothermal amplification (LAMP) technique has been developed to detect animal and plant pathogens (Notomi et al. 2000; Endo et al. 2004; Niessen 2015). A typical LAMP assay consists of serial reactions catalyzed by Bst DNA polymerase to amplify a target DNA sequence with the aid of a set of primers (four to six primers) under the isothermal condition (Notomi et al. 2000). The LAMP products can be visualized with naked eyes in the presence of some DNA-staining dyes such as SYBR Green I or ethidium bromide (Zhou et al. 2016; Long et al. 2017; Du et al. 2020). Compared to PCR, LAMP detection has advantages of high specificity, high efficiency, simplicity and rapidity, and more importantly, it does not require expensive and special instruments (Niessen 2015). LAMP has been used to detect L. maculans and L. biglobosa in infected plant tissues and air samples (Jedryczka et al. 2013; Zhou et al. 2016; Long et al. 2017; Du et al. 2020). However, LAMP detection and identification of the subclades of L. maculans and L. biglobosa has not been reported so far. Therefore, we have developed a LAMP-based technique for detection and identification of L. biglobosa 'brassicae', the prevalent subclade of L. biglobosa in China (Liu et al. 2014; Cai et al. 2015, 2018). The specific objectives include: (i) to design the LAMP primer set specific for L. biglobosa 'brassicae'; (ii) to optimize the LAMP-based technique; and (iii) to evaluate the potential of LAMP detection and identification of $L$. biglobosa 'brassicae' in field disease diagnosis and pathogen population survey.

\section{Materials and Methods}

Fungal isolates. A total of 45 fungal strains were used in this study, including 26 strains of L. biglobosa 'brassicae', 7 strains of L. biglobosa 'canadensis', 2 strains of L. maculans, 3 strains of other oilseed rape pathogens (Botrytis cinerea, Collectotrichum higginsianum, Sclerotinia sclerotiorum), and 7 strains of saprobes living on oilseed rape (Phoma spp., 
Alternaria alternatae, Chaetomium globosum) (Table 1). Two strains of L. maculans were isolated from seeds of canola (Brassica napus) imported from Canada by Dr. Zhenhua Wang of the Wuhan Customs Technical Centre (Wuhan, China). Strain 17-4 of L. biglobosa 'canadensis' was isolated from diseased seeds of canola (B. napus) also imported from Canada by Dr. Jianping Yi of the Shanghai Customs Technical Centre (Shanghai, China). The remains 42 fungal strains were isolated from oilseed rape collected from various locations in China (Table 1). All of the fungal strains were incubated on potato dextrose agar (PDA) with cellophane film overlays at $20^{\circ} \mathrm{C}$ for 3 to 15 days, mycelia and/or conidia of each strain were collected and stored at $-80^{\circ} \mathrm{C}$ until use.

LAMP primer designing. The specific LAMP primers for detection of L. biglobosa 'brassicae' were designed based on a DNA sequence selected from randomly amplified polymorphic DNA (RAPD) fragments. Strains Lb731 and W10 of L. biglobosa 'brassicae', strain 17-4 of L. biglobosa 'canadensis', strain 2010510-1 of L. maculans and strain P2 of Phoma macrostoma were used in the RAPD assays with 20 Operon primers listed in Table S1. Genomic DNA was extracted from the mycelia of these strains using the CTAB method (Möller et al. 1992) and used as templates in RAPD assays with the procedures described by Plummer and co-workers (1994). The resulting RAPD products were separated on a 1\% agarose gel (w/v) in Tris-Borate-EDTA (TBE) buffer $(89 \mathrm{mmol} / \mathrm{L}$ Tris, $89 \mathrm{mmol} / \mathrm{L}$ boric acid, and $2 \mathrm{mmol} / \mathrm{L}$ EDTA) and visualized on an UV trans-illuminator after staining with ethidium bromide $(1.5 \mathrm{mg} / \mathrm{mL})$. One of the DNA bands of approximately $600 \mathrm{bp}$ in size specific for $L$. biglobosa 'brassicae' (Fig. 1A) was selected as target for LAMP detection. It was purified from the agarose gel using AxyPrep DNA Gel Extraction Kit (Axygen Scientific, Inc., Union City, CA), cloned into Escherichia coli DH5a using the pMD18-T vector (TaKaRa Biotechnol. Co. Ltd., Dalian, China), and sequenced in Beijing AuGCT Biotechnol. Co. Ltd. The resulting DNA sequence (Figure S1) was searched by BLASTn on National Center for 
Biotechnology Information (NCBI) (https://www.ncbi.nlm.nih.gov/) to confirm its origin.

The result showed that the DNA sequence was 615 bp in length (Figure S1), it was $100 \%$ identical to the DNA sequence in the scaffold00021 of L. biglobosa 'brassicae' b35

(GenBank Acc. FO905643.1), and 88.13\% identical to a region in the genome of L. biglobosa 'canadensis' Lb1204 (Figure S2), however, no homologues to this DNA sequence were found in the genome of L. maculans JN3 (Genome Assembly No. GCA_900538235.1). Therefore, The DNA sequence appears to be highly specific for L. biglobosa 'brassicae'. Six LAMP primers were designed based on the DNA sequence using the LAMP primer designing software PrimerExplorer V5 at the website of http://www.primerexplorer.jp/lampv5e/ index.html (Fig. 1B, C, Table 2). The primers were synthesized by Beijing AuGCT Biotechnol. Co. Ltd. and used in the following LAMP assays.

LAMP optimization. The strain W10 of L. biglobosa 'brassicae' was used in this experiment. The LAMP mixtures $(25 \mu \mathrm{L})$ in 0.2 -mL Eppendorf tubes contained the following components (Table S2): $1 \times$ Isothermal Amplification Buffer (New England BioLabs ${ }^{\circledR}$ Inc, Ipswich, MA, USA), Bst 2.0 WarmStart ${ }^{\circledR}$ DNA Polymerase at $8 \mathrm{U}$ in each reaction mixture (New England BioLabs $\left.{ }^{\circledR}\right), \mathrm{MgSO}_{4}(4 \mathrm{mmol} / \mathrm{L})$, dNTPs $(10 \mathrm{mmol} / \mathrm{L}$ for each nucleotide), the forward and backward outer primers F3/B3 $(0.2 \mu \mathrm{mol} / \mathrm{L}$ for each), forward and backward loop primers $\mathrm{LF} / \mathrm{LB}(0.4 \mu \mathrm{mol} / \mathrm{L}$ for each), forward and inner primer backward FIP/BIP (1.6 $\mu \mathrm{mol} / \mathrm{L}$ for each), and template DNA ( $100 \mathrm{ng}$ for each reaction). The mixtures containing all the components except template DNA were used as controls. In order to prevent evaporation of the water in the mixtures during LAMP reaction, aliquots of liquid paraffin (Aladdin ${ }^{\circledR}$ Industrial Corporation, Shanghai, China) were added to the tubes with the LAMP mixtures (30 $\mu \mathrm{L}$ in each tube) as overlays. The LAMP reactions were performed in $1000^{\mathrm{TM}}$ Thermal Cycler (Bio-Rad Laboratories Inc., Hercules, CA) at $65^{\circ} \mathrm{C}$ for $50 \mathrm{~min}$ to determine the amplification efficiency of the primers, at $53^{\circ} \mathrm{C}, 55^{\circ} \mathrm{C}, 57^{\circ} \mathrm{C}, 59^{\circ} \mathrm{C}, 61^{\circ} \mathrm{C}, 63^{\circ} \mathrm{C}, 65^{\circ} \mathrm{C}, 67^{\circ} \mathrm{C}$, 
$69^{\circ} \mathrm{C}, 71^{\circ} \mathrm{C}, 73^{\circ} \mathrm{C}$ and $75^{\circ} \mathrm{C}$ for $40 \mathrm{~min}$ to optimize the temperature, and at $65^{\circ} \mathrm{C}$ for $10 \mathrm{~min}$, $20 \mathrm{~min}, 30 \mathrm{~min}, 40 \mathrm{~min}, 50 \mathrm{~min}, 60 \mathrm{~min}, 70 \mathrm{~min}$ and $80 \mathrm{~min}$ to optimize the time requirement. After LAMP amplification, the tubes were taken out from the thermal cycler and maintained at $4^{\circ} \mathrm{C}$ for at least $10 \mathrm{~min}$ to cool down the temperature in the reaction mixtures. Then, they were opened in another room next to the LAMP operation area, and aliquots of SYBR Green I solution at $100 \mu \mathrm{g} / \mathrm{mL}$ (Sigma-Aldrich ${ }^{\circledR}$, St. Louis, MO, USA) was added to the tubes at 0.2 $\mu \mathrm{L}$ per tube. Color change in the reaction mixtures was then observed, green coloration indicated a positive LAMP amplification, whereas brown coloration indicated a negative LAMP amplification. In order to confirm the LAMP amplification, $4 \mu \mathrm{L}$ LAMP product of each reaction was loaded in a $2 \%$ agarose gel $(\mathrm{w} / \mathrm{v})$. After electrophoresis, the gel was immersed in an ethidium bromide solution $(1.5 \mathrm{mg} / \mathrm{mL}, \mathrm{w} / \mathrm{v})$ for $30 \mathrm{~min}$, and the DNA fragments in the agarose gels were visualized on the UV trans-illuminator, formation of DNA mass ladders showing a multiple DNA bands pattern (or DNA ladder pattern) indicated a positive LAMP amplification and vice versa. Each LAMP reaction in this experiment as well as in the following experiments was repeated three times.

Specificity test. To test the specificity of the primers in LAMP detection of L. biglobosa 'brassicae', Genomic DNA was extracted from L. biglobosa 'brassicae' (26 strains), L. biglobosa 'canadensis' (7 strains), L. maculans (2 strains) and 10 strains of other fungi (Table 1) using the CTAB method (Möller et al. 1992). The DNA extracts were separately added to the LAMP mixtures, and the reactions were performed at $65^{\circ} \mathrm{C}$ for $40 \mathrm{~min}$. The LAMP products were visualized with SYBR Green I and confirmed by agarose gel electrophoresis.

Sensitivity test. Strain W10 of L. biglobosa 'brassicae' was used in this experiment for comparison of the detection thresholds in the LAMP and PCR assays, as the PCR assay was officially approved to detect L. biglobosa 'brassicae' in China (Zhao et al. 2015). The DNA solution $(132 \mathrm{ng} / \mu \mathrm{L})$ was 10 -fold diluted to generate the serial solutions with the DNA 
concentration decreasing from $132 \mathrm{ng} / \mu \mathrm{L}$ to $1.32 \mathrm{fg} / \mu \mathrm{L}$. An aliquot of $1 \mu \mathrm{L}$ of each DNA solution or water alone (control) was added to a LAMP mixture, which was incubated at $65^{\circ} \mathrm{C}$ for $40 \mathrm{~min}$. The LAMP products were visualized with SYBR Green I and confirmed by agarose gel electrophoresis. Meanwhile, the template sensitivity in LAMP detection was compared with that in the conventional PCR detection using the forward and backward outer primers F3 and B3 developed in this study (Table 2$)$. The PCR reaction mixtures $(25 \mu \mathrm{L})$ were prepared with the following components: $12.5 \mu \mathrm{L} 2 \times$ TSINGKE Master Mix (Tsingke Biol. Technol. Co. Ltd., Chengdu, China), $0.5 \mu \mathrm{L}$ forward primer F3 $(10 \mu \mathrm{mol} / \mathrm{L}), 0.5 \mu \mathrm{L}$ backward primer B3 (10 $\mu \mathrm{mol} / \mathrm{L}), 1.0 \mu \mathrm{L}$ DNA solution, and $10.5 \mu \mathrm{L}$ water. The PCR was performed in $1000^{\mathrm{TM}}$ Thermal Cycler with the following thermal program: initial denaturation at $94^{\circ} \mathrm{C}$ for $3 \mathrm{~min}$; followed by 36 cycles with denaturation at $94^{\circ} \mathrm{C}$ for $30 \mathrm{~s}$, annealing at $50^{\circ} \mathrm{C}$ for $30 \mathrm{~s}$ and extension at $72^{\circ} \mathrm{C}$ for $30 \mathrm{~s}$; and final extension at $72^{\circ} \mathrm{C}$ for 10 min. The PCR product (210 bp in size) was confirmed by agarose gel electrophoresis (Du et al. 2020).

LAMP-assisted fungal detection. Strain W10 of L. biglobosa 'brassicae' was used in this experiment. It was incubated at $20^{\circ} \mathrm{C}$ on PDA with cellophane film overlays for four days. Mycelia from 1, 2 or 3 square-shaped colony patches $(0.5 \mathrm{~cm} \times 0.5 \mathrm{~cm}$, length $\times$ width $)$ at the colony margin area were collected and put in 1.5-mL Eppendorf tubes. Aliquots of $1 \times$ TE buffer (100 mmol/L Tris-HCl, $10 \mathrm{mmol} / \mathrm{L}$ EDTA, $\mathrm{pH}$ 8.0) were transferred to the tubes at $50 \mu \mathrm{L}$ per tube. The mycelia were squashed using sterilized plastic pestles. The resulting mixtures were heat-treated in water bath at $95^{\circ} \mathrm{C}$ for 2 min for DNA release from the hyphal cells (Fan et al., 2018). After cooling down to the room temperature $\left(20 \pm 2{ }^{\circ} \mathrm{C}\right)$, the mixtures were centrifuged at $12,000 \mathrm{rpm}, 1 \mu \mathrm{L}$ supernatant of each sample was added to a LAMP mixture. In the control, $1 \mu \mathrm{L}$ sterilized water was added to the mixture. The LAMP amplifications were performed at $65^{\circ} \mathrm{C}$ for $40 \mathrm{~min}$, visualized with SYBR Green I and 
252 confirmed by agarose gel electrophoresis.

The PDA cultures of strain W10 were further incubated at $20^{\circ} \mathrm{C}$ for another 10 days for production of pycnidia and pycnidiospores (conidia), which were harvested by washing with sterilized water. Conidial concentration was measured using a hemocytometer. The master conidial suspension $\left(\sim 1 \times 10^{7}\right.$ conidia/mL) was 10 -fold diluted with sterilized water to generate serial conidial suspensions with the final concentrations at $2 \times 10^{5}, 2 \times 10^{4}, 2 \times 10^{3}$, $2 \times 10^{2}$ and 20 conidia/mL, and an aliquot of $100 \mu \mathrm{L}$ of each conidial suspension was pippeted to an Eppendorf tube containing $50 \mu \mathrm{L} 3 \times$ TE buffer. The conidial suspensions in the tubes were heat-treated in water bath $\left(95^{\circ} \mathrm{C}, 2 \mathrm{~min}\right)$, and after that, they were centrifuged at $12,000 \mathrm{rpm}$, and $1 \mu \mathrm{L}$ supernatant of each sample was added to the LAMP mixture. For the control, $1 \mu \mathrm{L}$ sterilized water was added to a LAMP mixture. The LAMP reactions were performed at $65^{\circ} \mathrm{C}$ for $40 \mathrm{~min}$, visualized with SYBR Green I and confirmed by agarose gel electrophoresis.

LAMP-assisted disease diagnosis. Diseased leaves, stems, mature pods and seeds of the winter-type oilseed rape (B. napus cultivar 'Zhongshuang No. 9') showing typical blackleg symptoms (Figure S3) were collected in the 2018-2019 season from a field in Shenshan Town of Chibi County, Hubei Province of China (2952'50"N, 114²3'48"E, $40 \mathrm{~m}$ high above sea level). Leaf samples were collected at the early flowering stage, and samples of stems, pods and seeds were collected at the harvest stage. The pathogen for the blackleg disease of oilseed rape and cruciferous vegetables in that area is L. biglobosa 'brassicae' according to the two-year surveys in our lab (Li 2019). Meanwhile, healthy leaves, stems, mature pods and seeds were collected and used as controls. Tissues were carefully taken from the collected samples using a sharp razor blade, tissue pieces $(\sim 5 \times 5 \mathrm{~mm}$, length $\times$ width $)$ were cut off from the leaves and the pod hulls, stem tissues $(\sim 5 \times 5 \mathrm{~mm}$, length $\times$ width $)$ were peeled off from the epidermal layer of the stems. The diseased leaf, stem and pod-hull pieces, 
or the diseased seeds were separately put in 1.5-mL Eppendorf tubes at 1,2 or 3 pieces (or seeds) in each tube. Meanwhile, two healthy tissue pieces or healthy seeds were put in other Eppendorf tubes as controls. Aliquots of $\mathrm{NaOH}$ solution $(0.4 \mathrm{~mol} / \mathrm{L})$ were added to the tubes,

$100 \mu \mathrm{L}$ per tube, and the plant tissue pieces or the seeds were squashed using sterilized

plastic pestles, followed by heat-treatment in water bath at $95^{\circ} \mathrm{C}$ for $2 \mathrm{~min}$. Then, the mixtures were centrifuged at $12,000 \mathrm{rpm}$, and $1 \mu \mathrm{L}$ supernatant of each sample was added to

a LAMP mixture as DNA template. The LAMP reactions were performed at $65^{\circ} \mathrm{C}$ for $40 \mathrm{~min}$ and visualized with SYBR Green I and confirmed by agarose gel electrophoresis.

\section{Results}

LAMP primers. Results of the RAPD assays showed that among the 20 tested 10-mer Operon primers (Table S1), OPA-19 persistently produced polymorphic DNA fragments among L. biglobosa 'brassicae', L. biglobosa ‘canadensis', L. maculans and Phoma macrostoma (Fig. 1A). Strains Lb731 and W10 of L. biglobosa 'brassicae' showed an identical DNA-banding pattern, which differed greatly from those in L. biglobosa ‘canadensis’ 17-4, L. maculans 2010510-1, and P. macrostoma P2. A DNA fragment of 615 bp in size from L. biglobosa 'brassicae' W10 was selected as target (Figure S1). It was uploaded into the on-line software PrimerExplorer V5 and six primers (forward and backward outer primers F3/B3, inner primers FIP/BIP, and loop primers LF/LB) were designed based on the 230-bp-long central region in that DNA sequence (Fig. 1B, C; Table 2).

LAMP optimization. In the assay for testing the LAMP amplification efficiency $\left(65^{\circ} \mathrm{C}\right.$, $50 \mathrm{~min}$ ), the control reaction mixture without any DNA templates retained a brown coloration in the presence of SYBR Green I, and did not produce any multiple DNA bands patterns when visualized on the agarose gel (Fig. 2A). However, the reaction mixture containing the DNA from strain W10 of L. biglobosa 'brassicae' exhibited a green coloration in presence of 
302 SYBR Green I, and it produced a multiple DNA bands pattern on the agarose gel. This result

suggests that the LAMP primers can efficiently amplify the DNA of L. biglobosa 'brassicae' strain W10.

The temperature and time duration required for LAMP detection of L. biglobosa 'brassicae' were optimized. In the temperature assay (40 min), a significant difference in the color of the reaction mixtures amended with SYBR Green I was observed among the temperature treatments ranging from $53^{\circ} \mathrm{C}$ to $75^{\circ} \mathrm{C}$ (Fig. 2B). In two low temperature treatments $\left(53^{\circ} \mathrm{C}, 55^{\circ} \mathrm{C}\right)$ and two high temperature treatments $\left(73^{\circ} \mathrm{C}\right.$ and $\left.75^{\circ} \mathrm{C}\right)$, the reaction mixtures retained a brown coloration without formation of multiple DNA bands patterns in agarose gels after electrophoresis, indicating no detectable LAMP amplifications in these four treatments. In the treatments at $57^{\circ} \mathrm{C}, 59^{\circ} \mathrm{C}, 63^{\circ} \mathrm{C}$ and $65^{\circ} \mathrm{C}$, the reaction mixtures had a green coloration and formed multiple DNA bands patterns in agarose gels after electrophoresis, moreover, the intensity of the green color showed an increase tendency with the temperatures increasing from $57^{\circ} \mathrm{C}$ to $65^{\circ} \mathrm{C}$. In the treatments at $67^{\circ} \mathrm{C}, 69^{\circ} \mathrm{C}$ and $71^{\circ} \mathrm{C}$, the reaction mixtures also showed a green coloration and formed multiple DNA bands patterns in agarose gels after electrophoresis, however, the intensity of the green color showed a decreased tendency with the temperatures increasing from $67^{\circ} \mathrm{C}$ to $71^{\circ} \mathrm{C}$. Therefore, the optimum temperature for LAMP detection of L. biglobosa 'brassicae' W10 was $65^{\circ} \mathrm{C}$. In the time duration assay $\left(65^{\circ} \mathrm{C}\right)$, the LAMP mixtures amended with SYBR Green I retained a brown coloration at $10 \mathrm{~min}$ post reaction $(\mathrm{mpr})$. The color of the reaction mixtures turned green when the time duration lasted between 20 and $80 \mathrm{mpr}$ (Fig. 2B). With the time duration extending to 20,30 and $40 \mathrm{mpr}$, the intensity of the green color gradually increased. The green color intensity had no visible change at the time duration longer than $50 \mathrm{mpr}$, suggesting that the LAMP reactions at 50 to 80 mpr may reach a plateau state. Therefore, the minimum time duration for LAMP detection of L. biglobosa 'brassicae' strain W10 was 40 
$\min$.

LAMP specificity. Results of the specificity assay showed that DNA from 45 fungi exhibited two different effects on LAMP amplification (Table 1). The reaction mixtures with the DNA from 26 strains of L. biglobosa 'brassicae' had a green coloration in the presence of SYBR Green I and formed multiple DNA bands patterns in agarose gels after electrophoresis. This result indicated that these reactions had a positive LAMP amplification. In contrast, the reaction mixtures with the DNA from 19 other fungi, including two close relatives of $L$. biglobosa 'brassicae' (L. biglobosa 'canadensis', L. maculans), three pathogens of oilseed rape (B. cinerea, Co. higginsianum, S. sclerotiorum), and seven saprobes living on oilseed rape (A. alternatae, Ch. globosum, Phoma spp.) retained a brown coloration and did not produce any multiple DNA bands patterns in agarose gels after electrophoresis. This result indicated that these LAMP reactions had a negative LAMP amplification. Therefore, the LAMP detection has a high specificity for L. biglobosa 'brassicae'.

LAMP sensitivity. Results of the sensitivity assay showed that the amount of the template DNA of L. biglobosa 'brassicae' in the reaction mixtures greatly affected LAMP amplification. The reaction mixtures with the amount of DNA per reaction ranging from 132 ng to $132 \mathrm{fg}$ had a green coloration in presence of SYBR Green I (Fig. 3A), and formed multiple DNA bands patterns in electrophored agarose gels (Fig. 3B). In contrast, the reaction mixtures with the amount of DNA per reaction at $13.2 \mathrm{fg}$ and $1.32 \mathrm{fg}$ and the control mixture without the template DNA retained a brown coloration in presence of SYBR Green I (Fig. 3A), and did not produce any multiple DNA bands patterns in the electrophored agarose gels (Fig. 3B). This result suggests that the minimum amount of the DNA in LAMP detection of $L$. biglobosa 'brassicae' is $132 \mathrm{fg}$ per reaction.

Results of the conventional PCR with the primers F3 and B3 (Table 2) indicated that after reaction, the PCR mixtures with the amount of the DNA template per reaction at $132 \mathrm{ng}$, 
$35213.2 \mathrm{ng}, 1.32 \mathrm{ng}$ or $132 \mathrm{pg}$ produced a DNA fragment with the expected size of $210 \mathrm{bp}$ (Fig.

3C). The brightness of the DNA band gradually became weaker with the amount of the DNA per reaction decreasing from $132 \mathrm{ng}$ to $132 \mathrm{pg}$. However, the PCR mixtures with the amount of the DNA template per reaction ranging from $13.2 \mathrm{pg}$ to $1.32 \mathrm{fg}$ did not produce any multiple DNA bands patterns in that agarose gel (Fig. 3C). Therefore, the LAMP detection appears 1000 times more sensitive than the PCR detection.

LAMP-assisted detection of $\boldsymbol{L}$. biglobosa 'brassicae'. The DNA from the mycelia and conidia of L. biglobosa 'brassicae' strain W10 was used as template in LAMP assays. The reaction mixtures containing the DNA from all the three mycelial samples and from 20 to 20000 conidia had a green coloration in the presence of SYBR Green I and produced multiple DNA bands patterns in electrophored agarose gels, indicating positive LAMP amplifications in these reactions (Table 3). In contrast, the control reaction mixtures without the DNA template and the reaction mixture containing the DNA from 2 conidia did not showed any visible color change in the presence of SYBR Green I and formation of multiple DNA bands patterns in the electrophored agarose gel was not observed at all (Table 3), indicating negative LAMP amplifications in these reactions.

LAMP-assisted diagnosis of the blackleg disease. The DNA from healthy and diseased tissues from leaves, stems, pods and seeds of oilseed rape (Figure S3) was used as template in LAMP assays. The results showed that the control mixtures containing the DNA from healthy leaves, stems, pods and seeds displayed a brown coloration in presence of SYBR Green I and did not produce any multiple DNA bands patterns in the agarose gels (Table 3), indicating negative LAMP amplifications in these reactions. However, the reaction mixtures containing the DNA from diseased leaves, stems, pods and seeds displayed a green coloration in presence of SYBR Green I (Table 3) and produced multiple DNA bands patterns on the agarose gels, indicating positive LAMP amplifications in these reactions. 


\section{Discussion}

This study developed a rapid, specific and sensitive LAMP assay for detection of $L$. biglobosa 'brassicae'. The use of LAMP as a tool to study the changing populations of $L$. maculans and L. biglobosa in diseased tissues of oilseed rape as well as in air samples was first reported in 2013 (Jedryczka et al. 2013). However, it is not clear what DNA sequence was used for designing of the LAMP primer set in that study (Jedryczka et al. 2013). In later studies, the internal transcribed spacer regions of the ribosomal DNA (ITS-rDNA) in $L$. maculans and L. biglobosa were used for designing the LAMP primer sets (Zhou et al. 2016; Long et al. 2017; Du et al. 2020). The resulting LAMP assays displayed a consistent detection of these two closely related pathogens (Zhou et al. 2016; Long et al. 2017; Du et al. 2020). However, whether these LAMP assays have specificity for subclades of L. maculans and L. biglobosa remains unknown. Omer and Wallenhammar (2020) reported real-time LAMP detection of L. maculans and L. biglobosa "brassicae". The primer sets SirP and PKS5 for L. maculans were designed based on the nucleotide sequences of the phytotoxin sirodesmin PL gene (sirP) and the polyketide synthase gene (PKS5). respectively, and the primer set PKS5 for L. biglobosa "brassicae" was designed based on the nucleotide sequences of the L. biglobosa "brassicae" PKS21 gene (Omer and Wallenhammar, 2020). In the present study, a 615-bp DNA sequence derived from a RAPD assay was used for designing the LAMP primer set. The resulting LAMP assay showed a positive detection of $L$. biglobosa 'brassicae', but failed to detect L. biglobosa 'canadensis' and L. maculans. Therefore, the LAMP assay has a high specificity for L. biglobosa 'brassicae'.

To the best of our knowledge, this is the first report about LAMP detection of $L$. biglobosa at the subclade level. The specificity may lie in the target DNA sequence, which is highly identical among strains of L. biglobosa 'brassicae', as it is a part of the genome of $L$. biglobosa 'brassicae' itself. However, the target DNA sequence has a low identity level 
$402(88.13 \%)$ to that in strains of L. biglobosa 'canadensis'. Moreover, no homologues to the target DNA sequence were identified in the genome of L. maculans. Future studies are

necessary to characterize the nature and location of the 615-bp DNA sequence in the genome of L. biglobosa 'brassicae' and to determine specificity of the primer set for other subclades of L. biglobosa, including 'americensis', 'australensis', ‘erysimii', 'occiaustralensis' and 'thlaspii', which belong to different branches from 'brassicae' and 'canadensis' in the phylogeneties inferred from the combined gene set ITS-rDNA, MAT1-2, actin gene (act) and $\beta$-tublin gene (Tub) as well as whole genomes (Vincenot et al. 2008; Dilmaghani et al. 2009; Grandaubert et al. 2014; Zou et al. 2019).

Previous studies indicated that the majority of the target DNA sequences used in the LAMP assays for fungi, yeasts and oomycetes are selected from public databases (Niessen 2015). The target DNA sequences include the ribosomal RNA genes in most cases, as well as many nuclear genes such as acl1, amyl, btub, cap59, gaoA, gp43, rodA, tef1, and ypt1 (Endo et al. 2004; Locas et al. 2010; Matsuzawa et al. 2010; Niessen and Vogel 2010; Huang et al. 2011; Luo et al. 2012; Niessen et al. 2012; Chen et al. 2013; Ferdousi et al. 2014; Niessen 2015). Meanwhile, quite a few previous studies reported use of RAPD assays to explore some novel DNA sequences as targets for LAMP detection of Verticillium dahliae, Fusarium oxysporum f.sp. cubense race 4, F. oxysporum f.sp. niveum and F. mangiferae (Li et al. 2013; Moradi et al. 2013; Peng et al. 2013; Pu et al. 2014). The present study selected a 615-bp-long RAPD sequence of L. biglobosa 'brassicae' as target in the LAMP assay for $L$. biglobosa 'brassicae'. The result corroborated the previous studies mentioned above that combined use of RAPD and LAMP is a valid strategy to develop the molecular techniques for detection and discrimination of the closely related plant pathogenic fungi.

The LAMP assay developed in this study provided a simple, rapid and efficient tool to diagnose the blackleg disease caused by L. biglobosa 'brassicae', and to assist identification 
427 of isolates of L. biglobosa 'brassicae'. Previous studies demonstrated that L. biglobosa 428 'brassicae' usually co-exists with L. maculans, L. biglobosa 'canadensis' and other minor 429 subclades of L. biglobosa (e.g. 'americensis', 'australensis' and 'occiaustralensis') (Voigt et 430 al, 2005; Fitt et al. 2006a; Vincenot et al. 2008; Dilmaghani et al. 2009; Zou et al. 2019). At 431 present, L. biglobosa 'brassicae' was found to be the sole causal agent for blackleg of oilseed 432 rape and cruciferous vegetables in China (Li et al. 2013; Liu et al. 2014; Cai et al. 2015, 433 2018). However, considering the situation of the continuous imports of seeds of oilseed rape 434 from foreign countries, L. maculans and other subclades of L. biglobosa might be introduced to this country (Fitt et al. 2008; Zhou et al. 2010; Wang et al. 2011; Zhang et al. 2014).

Therefore, it is necessary to persistently monitor the populations of the blackleg pathogens in oilseed rape-plantation areas as well as in the areas surrounding the import ports in China.

This study found that the LAMP assay could consistently detect the DNA extracted from the pure cultures of L. biglobosa 'brassicae' and from diseased plant tissues using the simplified DNA extraction methods (e.g. TE-buffer or alkaline lysis under $95^{\circ} \mathrm{C}$ for $2 \mathrm{~min}$ ), and the LAMP assay was performed within $2 \mathrm{~h}$. Using this technique together with the LAMP assays for L. maculans and L. biglobosa developed in previous studies (Zhou et al. 2016; Long et al. 2017; Du et al. 2020), it is possible to conduct a large-scale identification of the isolates of Leptosphaeria spp. and to carry out the on-site diagnosis of the blackleg disease in field surveys. Future studies are required to assemble the LAMP components into a kit and to optimize the LAMP assays under the field conditions.

\section{Acknowledgements}

This research was financially funded by the China Agriculture Research System (Grant CARS-12). We appreciate kind help from Dr. Zhenhua Wang of the Technical Center of the Wuhan Customs (Wuhan, China), and Dr. Jianping Yi of the Technical Center of the Shanghai Customs (Shanghai, China) for providing strains of L. biglobosa 'canadensis' and $L$. 
452 maculans.

\section{$453 \quad$ Literature cited}

454 Cai, X., Zhang, J., Wu, M. D., Jiang, D. H., Li, G. Q., and Yang, L. 2015. Effect of water 455 flooding on survival of Leptosphaeria biglobosa 'brassicae' in stubble of oilseed rape 456 (Brassica napus) in central China. Plant Dis. 99:1426-1433.

457 Cai, X., Huang, Y. J., Jiang, D. H., Fitt, B. D. L., Li, G. Q., and Yang, L. 2018. Evaluation of $458 \quad$ oilseed rape seed yield losses caused by Leptosphaeria biglobosa in central China. Eur. $459 \quad$ J. Plant Pathol. 150:179-190.

460 Chen, G. Y., Wu, C. P., Li, B., Su, H., Zhen, S. Z., and An, Y. L. 2010. Detection of $461 \quad$ Leptosphaeria maculans from imported canola seeds. J. Plant Dis. Protect. 117(4):173-176.

Chen, Q., Huang, F., Liao, F. R., Chen, H. Y., Yi, J. P., and Lin, S. M. 2013. Detection and identification of Leptosphaeria maculans from imported pakchoi (Brassica chinensis L.) seeds. Plant Quarantine 27(4):62-64.

Chigogora, J. L., and Hall, R. 1995. Relationships among measures of blackleg in winter oilseed rape and infection of harvested seed by Leptosphaeria maculans. Can. J. Plant Pathol. 17(1):25-30.

Dilmaghani, A., Balesdent, M. H., Didier, J. P., Wu, C., Davey, J., Barbetti, M. J., Li H., Moreno-Rico, O., Phillips, D., Despeghel, J. P., Vincenot, L., Gout, L., and Rouxel, T. 2009. The Leptosphaeria maculans-Leptosphaeria biglobosa species complex in the American continent. Plant Pathol. 58:1044-1058.

Du, R., Zhang, J., Yang, L., Wu, M. D., and Li, G. Q. 2020. Development of LAMP techniques to detect Leptosphaeria biglobosa and L. maculans in oilseed rape. Acta Phytopathol. Sin. DOI: 10.13926/j.cnki.apps.000514.

Endo, S., Komori, T., Ricci, G., Sano, A., Yokoyama, K., Ohori, A., Kamei, K., Franco, M., 
Miyaji, M., and Nishimura, K. 2004. Detection of gp43 of Paracoccidioides brasiliensis by the loop-mediated isothermal amplification (LAMP) method. FEMS Microbiol. Lett. 234:93-97.

Fan, F., Yin, W. X., Li, G. Q., Yin, L. F., and Luo, C. X. 2018. Development of a LAMP method for detecting SDHI fungicide resistance in Botrytis cinerea. Plant Dis. 102:1612-1618.

Ferdousi, A., Shahhossein, M. H., Bayat, M., Hashimi, S. J., and Gharhi, M. 2014. Comparison of polymerase chain reaction and loop-mediated isothermal amplification for diagnosis of Fusarium solani in human immunodeficiency virus positive patients. Afri. J. Biotechnol. 13:1496-1502.

Fitt, B. D. L., Huang, Y. J., van den Bosch, F., and West, J. S. 2006a. Coexistence of related pathogen species on arable crops in space and time. Annu. Rev. Phytopathol. $44: 163-182$.

Fitt, B. D. L., Brun, H., Barbetti, M. J., and Rimmer, S. R. 2006b. World-wide importance of phoma stem canker (Leptosphaeria maculans and L. biglobosa) on oilseed rape (Brassica napus). Eur. J. Plant Pathol. 114:3-15.

Fitt, B. D. L., Hu, B. C., Li, Z. Q., Liu, S. Y., Lange, R. M., Kharbanda, P. D., Butterworth, M. H., and White R. P. 2008. Strategies to prevent spread of Leptosphaeria maculans (phoma stem canker) onto oilseed rape crops in China; costs and benefits. Plant Pathol. $57: 652-664$.

Grandaubert, J., Lowe, R. G., Soyer, J. L., Schoch, C. L., van de Wouw, A. P., Fudal, I., Robbertse, B., Lapalu, N., Links, M. G., Ollivier, B., Linglin, J., Barbe, V., Mangenot, S., Cruaud, C., Borhan, H., Howlett, B. J., Balesdent, M., and Rouxel, T. 2014. Transposable element-assisted evolution and adaptation to host plant within the Leptosphaeria maculans-Leptosphaeria biglobosa species complex of fungal pathogens. 
BMC Genomics 15:891.

Gugel, R. K., and Petrie, G. A. 1992. History, occurrence, impact and control of blackleg of rapeseed. Can. J. Plant Pathol. 14:36-45.

Huang, C., Sun, Z., Yan, J., Luo, Y., Wang, H., and Ma, Z. 2011. Rapid and precise detection of latent infections of wheat stripe rust in wheat leaves using loop-mediated isothermal amplification. J. Phytopathol. 159:582-584.

Jedryczka, M., Burzynski, A., Brachaczek, A., Langwinski, W., Song, P., and Kaczmarek, J. 2013. Loop-mediated isothermal amplification as a good tool to study changing Leptosphaeria populations in oilseed rape plants and air samples. Acta Agrobot. 66:93-99.

Laing, M. D. 1986. The crucifer blackleg pathosystem in Natal, South Africa. Acta Horticult. 194:141-151.

Li, B. J., Du, J. L., Lan, C. Z., Liu, P. Q., Weng, Q. Y., and Chen, Q. H. 2013. Development of a loop-mediated isothermal amplification assay for rapid and sensitive detection of Fusarium oxysporum f.sp. cubense race 4. Eur. J. Plant Pathol. 135:903-911.

Li, J. C. 2019. Fixed-site monitoring of occurrence of blackleg of oilseed rape and characterization of infection by conidia of the pathogen. Master's degree dissertation of Huazhong Agricultural University (Wuhan, China). IV +61pp.

Li, Q. S., Rong, S. B., Hu, B. C., Jiang, Y. F., Hou, S. M., Fei, W. X. Chen, F. X., Wu, X. J., Fan, Z. X. and Lei, W. X. 2013. Distribution of blackleg disease on oilseed rape in China and its pathogen identification. Chin. J. Oil Crop Sci. 35:415-423.

Limonard, T. 1968. Ecological aspects of seed health testing. Proc. Interl. Seed Testing Assoc. 33(3): 64 .

Liu, S. Y., Liu, Z., Fitt, B. D. L., Evans, N., Foster, S. J., Huang, Y. J., Latunde-Dada, A. O., and Lucas, J. A. 2006. Resistance to Leptosphaeria maculans (phoma stem canker) in 
Brassica napus (oilseed rape) induced by L. biglobosa and chemical defense activators in field and controlled environments. Plant Pathology 55(3): 401-412.

Liu, Z., Latunde-Dada, A. O., Hall, A. M., and Fitt, B. D. L. 2014. Phoma stem canker disease on oilseed rape (Brassica napus) in China is caused by Leptosphaeria biglobosa 'brassicae'. Eur. J. Plant Pathol. 140:841-857.

Lob, S., Jaspers, M. V., Ridgway, H. J., and Jones, E. E. 2013. Leptosphaeria maculans/L. biglobosa disease progression in oilseed rape and timing of ascospore release under New Zealand conditions. New Zealand Plant Protect. 66:214-222.

Long, Y., Ma, X. H., Yuan, J. J., Lu, N. H., Yang, Z. Y., Wei, S. and Wang, W. F. 2017. Establishment of LAMP-HNB method for detection of Leptosphaeria maculans in rape. Guangdon Agri. Sci. 44:66-69.

Lucas, S., da Luz Martins, M., Flores, O., Meyer, W., Spencer-Martins, I., and Ina, J. 2010. Differentiation of Cryptococcus neoformans varieties and Cryptococcus gattii using CAP59-based loop-mediated isothermal DNA amplification. Clin. Microbiol. Infect. $16: 711-714$.

Luo, J., Vogel, R. F., and Niessen, L. 2012. Development and application of a loop-mediated isothermal amlification assay for rapid identification of aflatoxinogenic molds and their detection in food samples. Interl. J. Food Microbiol. 159:214-224.

Matsuzawa, T., Tanaka, R., Horie, Y., Gonoi, T., and Yaguchi, T. 2010. Development of rapid and specific molecular discrimination methods for pathogenic Emericella species. Japn. J. Med. Mycol. 51:109-115.

Mendes-Pereira, E., Balesdent, M., Brun, H., and Rouxel, T. 2003. Molecular phylogeny of the Leptosphaeria maculans-L. biglobosa species complex. Mycol. Res. 107:1287-1304.

Molina, J. P. E., Escande, A., Cendoya, G., and Quiroz, F. 2017. Qualitative and quantitative 
552 553

554

factors affecting the relationship between canola leaf spot epidemic and stem base canker (Leptosphaeria maculans) in Argentina. Australasian Plant Pathol. 46:453-461.

Möller, E. M., Bahnweg, G., Sandermann, H., and Geige, H. H. 1992. A simple and efficient protocol for isolation of high molecular weight DNA from filamentous fungi, fruit bodies, and infected plant tissues. Nucl. Acids Res. 20:6115-6116.

Moradi, A., Almasi, M.A., Jafary, H., and Mercado-Blanco, J. 2013. A novel and rapid loop-mediated isothermal amplification assay for the specific detection of Verticillium dahliae. J. Appl. Microbiol. 116:942-954.

Niessen, L., and Vogel, R. F. 2010. Detection of Fusarium graminearum DNA using a loop-mediated isothermal amplification (LAMP) assay. Interl. J. Food Microbiol. 140:183-191.

Niessen, L., Gräfenhan, T., and Vogel, R. F. 2012. ATP citrate lyase 1 ( acll) gene based loop-mediated amplification assay for the detection of the Fusarium tricinctum species complex in pure cultures and in cereal samples. Interl. J. Food Microbiol. 158:171-185.

Niessen, L. 2015. Current state and future perspectives of loop-mediated isothermal amplification (LAMP)-based diagnosis of filamentous fungi and yeasts. Appl. Microbiol. Biotechnol. 99:553-574.

Notomi, T., Okayama, H., Masubuchi, H., Yonekawa, T., Watanabe, K., Amino, N., and Hase, T. 2000. Loop-mediated isothermal amplification of DNA. Nucl. Acids Res. 28:e63.

Omer, Z. S., and Wallenhammar, A. -C. 2020. Development of loop-mediated isothermal amplification assays for rapid detection of blackleg pathogens in Swedish winter oil seed rape. Eur. J. Plant Pathol. 157:353-365.

Peng, J., Zhan, Y. F., Zeng F. Y., Long, H. B., Pei, Y. L., and Guo, J. R. 2013. Development of a real-time fluorescence loop-mediated isothermal amplification assay for rapid and 

quantitative detection of Fusarium oxysporum f.sp. niveum in soil. FEMS Microbiol. Lett. 349:127-134.

Piening, L., Okolo, E., and Harder, D. 1975. Blackleg of rapeseed in Kenya. East Afr. Agri. For. J. 41:110-113.

Plummer, K. M., Dunse, K., and Howlett, B. J. 1994. Non-aggressive strains of the blackleg fungus, Leptosphaeria maculans, are present in Australia and can be distinguished from aggressive strains by molecular analysis. Aus. J. Bot. 42:1-8.

Pu, J. J., Xie, Y. X., Zhang, H., Zhang, X., Qi, Y. X., and Peng, J. 2014. Development of a real-time fluorescence loop-mediated isothermal amplification assay for rapid and quantitative detection of Fusarium mangiferae associated with mango malformation. Physiol. Mol. Plant Pathol. 86:81-88.

Rong, S. B., Hu, B. C., Chen, F. X., Wu, X. J. Hou, S. M., Fei, W. X., and Li, Q. S. 2015. Effects of Leptosphaeria biglobosa on seed yield and related traits of oilseed rape. Crops (6):159-161.

Salisbury, P. A., Ballinger, D. J., Wratten, N., Plummer, K. M., and Howlett, B. J. 1995. Blackleg disease on oilseed Brassica in Australia: a review. Aus. J. Exper. Agri. 35:665-672.

Shoemaker, R. A., and Brun, H. 2001. The teleomorph of the weakly aggressive segregate of Leptosphaeria maculans. Can. J. Bot. 79:412-419.

Vincenot, L., Balesdent, M. H., Li, H., Barbetti, M. J., Sivasithamparam, K., Gout, L., and Rouxel, T. 2008. Occurrence of a new subclade of Leptosphaeria biglobosa in Western Australia. Phytopathology 98:321-329.

van de Wouw, A. P., Thomas, V. L., Cozijnsen, A. J., Marcroft, S. J., Salisbury, P. A., and Howlett, B. J. 2008. Identification of Leptosphaeria biglobosa 'canadensis' on Brassica juncea stubble from northern New South Wales, Australia. Australasian Plant Dis. Notes 
602 603 604 3:124-128.

Voigt, K., Cozijnsen, A. J., Kroymann, J., Pöggeler, S., and Howlett, B. J. 2005. Phylogenetic relationships between members of the crucifer pathogenic Leptosphaeria maculans species complex as shown by mating type (MAT1-2), actin, and $\beta$-tubulin sequences. Mol. Phylogen. Evol. 37:541-557.

Wang, T., Wang, C. N., Zhang, H., Wen, J. J., and Zhang, B. 2017. Study on rapid extraction of genomic DNA from Chinese cabbage. Acta Agri. Boreali-Sin. 32:67-72.

Wang, G. P., Hu, K. L., and Jedryczka, M. 2003. Health testing and evaluation of Leptosphaeria maculans (Phoma lingam) contamination in Brassica napus seed samples from Poland and England. J. South China Agri. Univ. (Nat. Sci. Ed.) 24(4):28-31.

Wang, Z. H., Yang, W., Zhao, H., Zeng, X. D., Li, F. X., Cai, X., Wang, H. C., and Yu, H. 2011. Detection and identification of Leptosphaeria maculans in imported Canadian rapeseeds. J. Huazhong Agri. Univ. 30(1):66-69.

West, J. S., Evans, N., Liu, S., Hu, B., and Peng, L. 2000. Leptosphaeria maculans causing stem canker of oilseed rape in China. Plant Pathol. 49:800.

West, J. S., Kharbanda, P., Barbetti, M. J., and Fitt, B. D. L. 2001. Epidemiology and management of Leptosphaeria maculans (phoma stem canker) in Australia, Canada and Europe. Plant Pathol. 50:10-27.

Williams, R. H., and Fitt, B. D. L. 1999. Differentiating A and B groups of Leptosphaeria maculans, causal agent of stem canker (blackleg) of oilseed rape. Plant Pathol. $48: 161-175$.

Zhang, X., White, R. P., Demir, E., Jedryczkae, M., Lange, R. M., Islam, M., Li, Z. Q., Huang, Y. J., Hall, A. M., Zhou, G., Wang, Z., Cai, X., Skelsey, P., and Fitt, B. D. L. 2014. Leptosphaeria spp., phoma stem canker and potential spread of L. maculans on oilseed rape crops in China. Plant Pathol. 63:598-612. 
Zhao, H., Wang, Z. H., Zeng, X. D., Yi, J. P., Li, B., Li,G. Q., Wu, P. S., and Cai, X. 2015

\section{Detection and identification of Plenodomus biglobosus. GB/T 31798-2015. Released by}

\section{General Administration of Quality Supervision, Inspection and Quarantine of the}

\section{People's Republic of China, and China National Standardizing Committee}

Zhou, G. L., Shang, L. L., Yu, C., Yin, L. P., Xu, D. S., and Yi, J. P. 2010. Detection of Leptosphaeria maculans and L. biglobosa in oilseed rape samples imported from Australia. Acta Phytophyl. Sin. 37(4):289-294.

Zhou, Y., Huang, H. L., Li, X. J., Shan, C. L., Li, X. S., Chen, Y., Shao, W. D., and Zhu, P. 2016. Establishment of Leptosphaeria maculans detection by loop-mediated isothermal amplification combined with a lateral-flow dipstick. Plant Quarantine 30(4):32-37.

Zou, Z. W., Zhang, X. H., Parks, P., du Toit, L. J., van de Wouw, A. P., and Fernando W. G. D. 2019. A new subclade of Leptosphaeria biglobosa identified from Brassica rapa. Interl. J. Mol. Sci. 20:1668. 
1 LAMP Detection and Identification of the Blackleg Pathogen Leptosphaeria biglobosa 2 'brassicae'

\section{3}

4 Ran Du, State Key Laboratory of Agricultural Microbiology, Huazhong Agricultural

5 University, Wuhan 430070, China; Y. J. Huang, School of Life and Medical Sciences,

6 University of Hertfordshire, AL10 9, Hatfield, AB, UK; Jing Zhang, Long Yang, Mingde

7 Wu, and Guoqing Li, State Key Laboratory of Agricultural Microbiology, Huazhong

8 Agricultural University, Wuhan 430070, China

$9 \quad$ Correspondence: Dr. G. Q. Li, E-mail: guoqingli@mail.hzau.edu.cn 


\section{Abstract}

Blackleg of oilseed rape is a damaging invasive disease caused by the species complex Leptosphaeria maculans $(\mathrm{Lm}) /$ L. biglobosa $(\mathrm{Lb})$, which are composed of at least two and seven phylogenetic subclades, respectively. Generally, Lm is more virulent than Lb, however, under certain conditions, Lb can cause a significant yield loss in oilseed rape. Lb 'brassicae' (Lbb) has been found to be the causal agent for blackleg of oilseed rape in China, whereas Lm and Lb 'canadensis' (Lbc) were frequently detected in imported seeds of oilseed rape, posing a risk of spread into China. In order to monitor the blackleg-pathogen populations, a diagnostic tool based on loop-mediated isothermal amplification (LAMP) was developed using a 615-bp-long DNA sequence from Lbb that was derived from a randomly amplified polymorphic DNA assay. The LAMP was optimized for temperature and time, and tested for specificity and sensitivity using the DNA extracted from Lbb, Lbc, Lm, and 10 other fungi. The results showed that the optimal temperature and time were $65^{\circ} \mathrm{C}$ and $40 \mathrm{~min}$, respectively. The LAMP primer set was specific to Lbb and highly sensitive as it detected the Lbb DNA as low as $132 \mathrm{fg}$ per reaction. The LAMP assay was validated using the DNA extracted from mycelia and conidia of a well-characterized Lbb isolate, and its utility was evaluated using the DNA extracted from leaves, stems, pods and seeds of oilseed rape. The LAMP assay developed herein will help for monitoring populations of the blackleg pathogens in China and developing strategies for management of the blackleg disease. 
Blackleg (phoma stem canker) of oilseed rape (Brassica napus) is a world-wide economically important disease (Piening et al. 1975; Gugel and Petrie 1992; Laing 1986;

Salisbury et al. 1995; Dilmaghani et al. 2000; West et al. 2000; Fitt et al. 2006; Lob et al. 2013; Molina et al. 2017). It is caused by two closely related and morphologically similar ascomycetous fungi, Leptosphaeria maculans (anamorph: Plenodomus lingam) and Leptosphaeria biglobosa (anamorph: Plenodomus biglobosus), which form a species complex (Mendes-Pereira et al. 2003). Both fungi can infect leaves, stems and pods of oilseed rape, causing phoma leaf spots, phoma stem cankers and phoma pod spots, respectively (Fitt et al. 2006b). Among these symptoms, phoma stem canker is the most important regarding seed yield loss, as it can cause stem collapse (lodging), thereby reducing seed production.

Numerous studies indicated that L. maculans is more virulent than L. biglobosa in terms of the extent of damage to the plants and seed production, as L. maculans can invade into the vascular tissue of the basal stem, where it may cause stem collapse, in contrast, L. biglobosa usually infects the epidermal tissue of the upper stem, where it rarely causes stem collapse (Plummer et al. 1994; Williams and Fitt 1999; West et al. 2001; Fitt et al. 2006a). Previous studies showed that the L. maculans/L. biglobosa species complex (especially L. maculans) is responsible for serious economic losses to the industry of oilseed rape (or canola) in Australia, Canada, France, Germany and UK since the 1970s. It was estimated that the blackleg disease of oilseed rape caused an average annual economic loss of US\$167 million during 1983 to 1998 in Alberta of Canada, and US\$70 million during 2000 to 2002 in the UK (Fitt et al. 2006b, 2008).

In China, blackleg of oilseed rape was first reported in the early 2000s, and the pathogen for that disease was identified as NA1 or B-group of L. maculans (West et al. 2000), which was later re-classified as L. biglobosa (Shoemaker and Brun, 2001). Large-scale field surveys demonstrated that this disease widely occurred in oilseed rape-plantation areas (Li et al. 
2013). Compared to healthy plants, diseased plants had less yield with the average single-plant seed yield loss ranging from $10 \%$ to $56 \%$ (Rong et al. 2015; Cai et al. 2018). So far, only L. biglobosa has been found in oilseed rape and cruciferous vegetables in China (Fitt et al. 2008; Li et al. 2013; Liu et al. 2014; Zhang et al. 2014; Cai et al. 2015, 2018), and L. maculans was thus officially considered as a quarantine pathogen since the late 2000s (Zhou et al. 2010; Wang et al. 2011).

Both L. maculans and L. biglobosa can be further classified into subclades or subspecies based on phylogenetic analysis of the nucleotide sequences of the internal transcribed spacer region of ribosomal DNA (ITS-rDNA), and a few nuclear genes such as the mating type gene MAT1-2 and the genes coding for actin and $\beta$-tubulin (Mendes-Pereira et al. 2003). So far, two subclades have been identified in L. maculans, including 'brassicae' on Brassica and 'lepidii' on Lepidium sp. (Mendes-Pereira et al. 2003). Seven subclades have been identified in L. biglobosa, including 'americensis', 'australensis', 'brassicae', 'canadensis' and 'occiaustralensis' on Brassica spp., 'erysimii' on Erysimum, and 'thlaspii' on Thlaspi sp. (Voigt et al. 2005; Vincenot et al. 2008; Zou et al. 2019). Among these L. biglobosa subclades, 'brassicae' and 'canadensis' are the most common and important, L. biglobosa 'brassicae' has been found in the continents of America, Asia and Europe (Fitt et al. 2006a; Vincenot et al. 2008; Dilmaghani et al. 2009; Liu et al. 2014), and L. biglobosa 'canadensis' has been detected in the continent of America (Canada, USA) as well as in Australia (van de Wouw et al. 2008; Dilmaghani et al. 2009; Liu et al. 2014). Five other subcluades of $L$. biglobosa, including 'americensis', 'australensis', 'erysimii', 'occiaustralensis' and 'thlaspii' are the minor subclades, 'americensis' was only found in USA (Zou et al. 2019), 'erysimii' was found in Canada (Voigt et al. 2005), 'australensis' and 'occiaustralensis' were found in Australia (Vincenot et al. 2008).

It is well recognized that L. maculans and L. biglobosa can be spread over a long 
102 distance through international trade of seeds of oilseed rape and/or exchange of germplasm resources of cruciferous crops (Chigogora and Hall 1995; Wang et al. 2003; Chen et al. 2010; Zhou et al. 2010; Wang et al. 2011; Chen et al. 2013). Therefore, detection and identification of L. maculans and L. biglobosa in crop seeds is essential in preventing spread of these two pathogens into other regions. Since the late 1970s, the deep-freezing blotter method has been recommended by the International Seed Testing Association (ISTA) to detect L. maculans and L. biglobosa in contaminated or infected seeds of cruciferous crops, including oilseed rape (Limonard 1968). The key point in that method is inhibition of seed germination under freezing temperatures (e.g. $-20^{\circ} \mathrm{C}$ ) and the subsequent promotion of growth of the seedborne fungi on the seeds under normal temperatures (e.g. $20^{\circ} \mathrm{C}$ ) (Wang et al. 2003).

Moreover, monitoring of the populations of L. maculans and L. biglobosa in fields planted with oilseed rape and cruciferous vegetables is also important regarding management of the blackleg disease (West et al. 2001; Dilmaghani et al. 2009). L. maculans and L. biglobosa usually produce similar symptoms on stems with formation of abundant black pycnidia (West et al. 2001; Li et al. 2013). Therefore, it is difficult to distinguish these two pathogens just based on disease symptoms and location of infection (e.g. basal and upper stems) and the disease symptoms. Many researchers have made efforts to develop simple, rapid and accurate methods to detect and identify L. maculans and L. biglobosa on diseased plant tissues. The methods so far developed include plant assays (e.g. virulence tests), morphological characterization (e.g. colony growth, pseudothecial shape, ascospore germlings), metabolite profiling (e.g. pigments, phytotoxins), typing of glucose phosphate isomerase, karyotyping, serological typing, DNA analyses (e.g. RFLP, RAPD, PCR) and genome analyses (Williams and Fitt, 1999; Mendes-Pereira et al., 2003; Liu et al., 2006; van de Wouw et al., 2008. Vincenot et al. 2008; Grandaubert et al. 2014). However, these methods are usually time-consuming, labor-intensive and/or dependent on special expertise 
and instruments. There is a need to develop simpler, faster and more convenient methods for detection and identification of these two pathogens.

Since the early 2000s, loop-mediated isothermal amplification (LAMP) technique has been developed to detect animal and plant pathogens (Notomi et al. 2000; Endo et al. 2004; Niessen 2015). A typical LAMP assay consists of serial reactions catalyzed by Bst DNA polymerase to amplify a target DNA sequence with the aid of a set of primers (four to six primers) under the isothermal condition (Notomi et al. 2000). The LAMP products can be visualized with naked eyes in the presence of some DNA-staining dyes such as SYBR Green I or ethidium bromide (Zhou et al. 2016; Long et al. 2017; Du et al. 2020). Compared to PCR, LAMP detection has advantages of high specificity, high efficiency, simplicity and rapidity, and more importantly, it does not require expensive and special instruments (Niessen 2015). LAMP has been used to detect L. maculans and L. biglobosa in infected plant tissues and air samples (Jedryczka et al. 2013; Zhou et al. 2016; Long et al. 2017; Du et al. 2020). However, LAMP detection and identification of the subclades of L. maculans and L. biglobosa has not been reported so far. Therefore, we have developed a LAMP-based technique for detection and identification of L. biglobosa 'brassicae', the prevalent subclade of L. biglobosa in China (Liu et al. 2014; Cai et al. 2015, 2018). The specific objectives include: (i) to design the LAMP primer set specific for L. biglobosa 'brassicae'; (ii) to optimize the LAMP-based technique; and (iii) to evaluate the potential of LAMP detection and identification of $L$. biglobosa 'brassicae' in field disease diagnosis and pathogen population survey.

\section{Materials and Methods}

Fungal isolates. A total of 45 fungal strains were used in this study, including 26 strains of L. biglobosa 'brassicae', 7 strains of L. biglobosa 'canadensis', 2 strains of L. maculans, 3 strains of other oilseed rape pathogens (Botrytis cinerea, Collectotrichum higginsianum, Sclerotinia sclerotiorum), and 7 strains of saprobes living on oilseed rape (Phoma spp., 
Alternaria alternatae, Chaetomium globosum) (Table 1). Two strains of L. maculans were isolated from seeds of canola (Brassica napus) imported from Canada by Dr. Zhenhua Wang of the Wuhan Customs Technical Centre (Wuhan, China). Strain 17-4 of L. biglobosa 'canadensis' was isolated from diseased seeds of canola (B. napus) also imported from Canada by Dr. Jianping Yi of the Shanghai Customs Technical Centre (Shanghai, China). The remains 42 fungal strains were isolated from oilseed rape collected from various locations in China (Table 1). All of the fungal strains were incubated on potato dextrose agar (PDA) with cellophane film overlays at $20^{\circ} \mathrm{C}$ for 3 to 15 days, mycelia and/or conidia of each strain were collected and stored at $-80^{\circ} \mathrm{C}$ until use.

LAMP primer designing. The specific LAMP primers for detection of L. biglobosa 'brassicae' were designed based on a DNA sequence selected from randomly amplified polymorphic DNA (RAPD) fragments. Strains Lb731 and W10 of L. biglobosa 'brassicae', strain 17-4 of L. biglobosa 'canadensis', strain 2010510-1 of L. maculans and strain P2 of Phoma macrostoma were used in the RAPD assays with 20 Operon primers listed in Table S1. Genomic DNA was extracted from the mycelia of these strains using the CTAB method (Möller et al. 1992) and used as templates in RAPD assays with the procedures described by Plummer and co-workers (1994). The resulting RAPD products were separated on a 1\% agarose gel (w/v) in Tris-Borate-EDTA (TBE) buffer $(89 \mathrm{mmol} / \mathrm{L}$ Tris, $89 \mathrm{mmol} / \mathrm{L}$ boric acid, and $2 \mathrm{mmol} / \mathrm{L}$ EDTA) and visualized on an UV trans-illuminator after staining with ethidium bromide $(1.5 \mathrm{mg} / \mathrm{mL})$. One of the DNA bands of approximately $600 \mathrm{bp}$ in size specific for $L$. biglobosa 'brassicae' (Fig. 1A) was selected as target for LAMP detection. It was purified from the agarose gel using AxyPrep DNA Gel Extraction Kit (Axygen Scientific, Inc., Union City, CA), cloned into Escherichia coli DH5a using the pMD18-T vector (TaKaRa Biotechnol. Co. Ltd., Dalian, China), and sequenced in Beijing AuGCT Biotechnol. Co. Ltd. The resulting DNA sequence (Figure S1) was searched by BLASTn on National Center for 
Biotechnology Information (NCBI) (https://www.ncbi.nlm.nih.gov/) to confirm its origin.

The result showed that the DNA sequence was 615 bp in length (Figure S1), it was 100\% identical to the DNA sequence in the scaffold00021 of L. biglobosa 'brassicae' b35

(GenBank Acc. FO905643.1), and 88.13\% identical to a region in the genome of L. biglobosa 'canadensis' Lb1204 (Figure S2), however, no homologues to this DNA sequence were found in the genome of L. maculans JN3 (Genome Assembly No. GCA_900538235.1). Therefore, The DNA sequence appears to be highly specific for L. biglobosa 'brassicae'. Six LAMP primers were designed based on the DNA sequence using the LAMP primer designing software PrimerExplorer V5 at the website of http://www.primerexplorer.jp/lampv5e/ index.html (Fig. 1B, C, Table 2). The primers were synthesized by Beijing AuGCT Biotechnol. Co. Ltd. and used in the following LAMP assays.

LAMP optimization. The strain W10 of L. biglobosa 'brassicae' was used in this experiment. The LAMP mixtures $(25 \mu \mathrm{L})$ in 0.2 -mL Eppendorf tubes contained the following components (Table S2): $1 \times$ Isothermal Amplification Buffer (New England BioLabs ${ }^{\circledR}$ Inc, Ipswich, MA, USA), Bst 2.0 WarmStart ${ }^{\circledR}$ DNA Polymerase at $8 \mathrm{U}$ in each reaction mixture (New England BioLabs $\left.{ }^{\circledR}\right), \mathrm{MgSO}_{4}(4 \mathrm{mmol} / \mathrm{L})$, dNTPs $(10 \mathrm{mmol} / \mathrm{L}$ for each nucleotide), the forward and backward outer primers F3/B3 $(0.2 \mu \mathrm{mol} / \mathrm{L}$ for each), forward and backward loop primers $\mathrm{LF} / \mathrm{LB}(0.4 \mu \mathrm{mol} / \mathrm{L}$ for each), forward and inner primer backward FIP/BIP (1.6 $\mu \mathrm{mol} / \mathrm{L}$ for each), and template DNA ( $100 \mathrm{ng}$ for each reaction). The mixtures containing all the components except template DNA were used as controls. In order to prevent evaporation of the water in the mixtures during LAMP reaction, aliquots of liquid paraffin (Aladdin ${ }^{\circledR}$ Industrial Corporation, Shanghai, China) were added to the tubes with the LAMP mixtures (30 $\mu \mathrm{L}$ in each tube) as overlays. The LAMP reactions were performed in $1000^{\mathrm{TM}}$ Thermal Cycler (Bio-Rad Laboratories Inc., Hercules, CA) at $65^{\circ} \mathrm{C}$ for $50 \mathrm{~min}$ to determine the amplification efficiency of the primers, at $53^{\circ} \mathrm{C}, 55^{\circ} \mathrm{C}, 57^{\circ} \mathrm{C}, 59^{\circ} \mathrm{C}, 61^{\circ} \mathrm{C}, 63^{\circ} \mathrm{C}, 65^{\circ} \mathrm{C}, 67^{\circ} \mathrm{C}$, 
$20269^{\circ} \mathrm{C}, 71^{\circ} \mathrm{C}, 73^{\circ} \mathrm{C}$ and $75^{\circ} \mathrm{C}$ for $40 \mathrm{~min}$ to optimize the temperature, and at $65^{\circ} \mathrm{C}$ for $10 \mathrm{~min}$, $20320 \mathrm{~min}, 30 \mathrm{~min}, 40 \mathrm{~min}, 50 \mathrm{~min}, 60 \mathrm{~min}, 70 \mathrm{~min}$ and $80 \mathrm{~min}$ to optimize the time requirement.

204 After LAMP amplification, the tubes were taken out from the thermal cycler and maintained 205 at $4{ }^{\circ} \mathrm{C}$ for at least $10 \mathrm{~min}$ to cool down the temperature in the reaction mixtures. Then, they 206 were opened in another room next to the LAMP operation area, and aliquots of SYBR Green 207 I solution at $100 \mu \mathrm{g} / \mathrm{mL}$ (Sigma-Aldrich ${ }^{\circledR}$, St. Louis, MO, USA) was added to the tubes at 0.2 $208 \mu \mathrm{L}$ per tube. Color change in the reaction mixtures was then observed, green coloration LAMP amplification. In order to confirm the LAMP amplification, $4 \mu \mathrm{L}$ LAMP product of each reaction was loaded in a $2 \%$ agarose gel $(\mathrm{w} / \mathrm{v})$. After electrophoresis, the gel was immersed in an ethidium bromide solution $(1.5 \mathrm{mg} / \mathrm{mL}, \mathrm{w} / \mathrm{v})$ for $30 \mathrm{~min}$, and the DNA fragments in the agarose gels were visualized on the UV trans-illuminator, formation of DNA mass ladders showing a multiple DNA bands pattern (or DNA ladder pattern) indicated a positive LAMP amplification and vice versa. Each LAMP reaction in this experiment as well as in the following experiments was repeated three times.

Specificity test. To test the specificity of the primers in LAMP detection of L. biglobosa 'brassicae', Genomic DNA was extracted from L. biglobosa 'brassicae' (26 strains), L. biglobosa 'canadensis' (7 strains), L. maculans (2 strains) and 10 strains of other fungi (Table 1) using the CTAB method (Möller et al. 1992). The DNA extracts were separately added to the LAMP mixtures, and the reactions were performed at $65^{\circ} \mathrm{C}$ for $40 \mathrm{~min}$. The LAMP products were visualized with SYBR Green I and confirmed by agarose gel electrophoresis.

Sensitivity test. Strain W10 of L. biglobosa 'brassicae' was used in this experiment for comparison of the detection thresholds in the LAMP and PCR assays, as the PCR assay was officially approved to detect L. biglobosa 'brassicae' in China (Zhao et al. 2015). The DNA solution $(132 \mathrm{ng} / \mu \mathrm{L})$ was 10 -fold diluted to generate the serial solutions with the DNA 
concentration decreasing from $132 \mathrm{ng} / \mu \mathrm{L}$ to $1.32 \mathrm{fg} / \mu \mathrm{L}$. An aliquot of $1 \mu \mathrm{L}$ of each DNA solution or water alone (control) was added to a LAMP mixture, which was incubated at $65^{\circ} \mathrm{C}$ for $40 \mathrm{~min}$. The LAMP products were visualized with SYBR Green I and confirmed by agarose gel electrophoresis. Meanwhile, the template sensitivity in LAMP detection was compared with that in the conventional PCR detection using the forward and backward outer primers F3 and B3 developed in this study (Table 2$)$. The PCR reaction mixtures $(25 \mu \mathrm{L})$ were prepared with the following components: $12.5 \mu \mathrm{L} 2 \times$ TSINGKE Master Mix (Tsingke Biol. Technol. Co. Ltd., Chengdu, China), $0.5 \mu \mathrm{L}$ forward primer F3 $(10 \mu \mathrm{mol} / \mathrm{L}), 0.5 \mu \mathrm{L}$ backward primer B3 (10 $\mu \mathrm{mol} / \mathrm{L}), 1.0 \mu \mathrm{L}$ DNA solution, and $10.5 \mu \mathrm{L}$ water. The PCR was performed in $1000^{\mathrm{TM}}$ Thermal Cycler with the following thermal program: initial denaturation at $94^{\circ} \mathrm{C}$ for $3 \mathrm{~min}$; followed by 36 cycles with denaturation at $94^{\circ} \mathrm{C}$ for $30 \mathrm{~s}$, annealing at $50^{\circ} \mathrm{C}$ for $30 \mathrm{~s}$ and extension at $72^{\circ} \mathrm{C}$ for $30 \mathrm{~s}$; and final extension at $72^{\circ} \mathrm{C}$ for 10 min. The PCR product (210 bp in size) was confirmed by agarose gel electrophoresis (Du et al. 2020).

LAMP-assisted fungal detection. Strain W10 of L. biglobosa 'brassicae' was used in this experiment. It was incubated at $20^{\circ} \mathrm{C}$ on PDA with cellophane film overlays for four days. Mycelia from 1, 2 or 3 square-shaped colony patches $(0.5 \mathrm{~cm} \times 0.5 \mathrm{~cm}$, length $\times$ width $)$ at the colony margin area were collected and put in 1.5-mL Eppendorf tubes. Aliquots of $1 \times$ TE buffer (100 mmol/L Tris-HCl, $10 \mathrm{mmol} / \mathrm{L}$ EDTA, $\mathrm{pH}$ 8.0) were transferred to the tubes at $50 \mu \mathrm{L}$ per tube. The mycelia were squashed using sterilized plastic pestles. The resulting mixtures were heat-treated in water bath at $95^{\circ} \mathrm{C}$ for 2 min for DNA release from the hyphal cells (Fan et al., 2018). After cooling down to the room temperature $\left(20 \pm 2{ }^{\circ} \mathrm{C}\right)$, the mixtures were centrifuged at $12,000 \mathrm{rpm}, 1 \mu \mathrm{L}$ supernatant of each sample was added to a LAMP mixture. In the control, $1 \mu \mathrm{L}$ sterilized water was added to the mixture. The LAMP amplifications were performed at $65^{\circ} \mathrm{C}$ for $40 \mathrm{~min}$, visualized with SYBR Green I and 
252 confirmed by agarose gel electrophoresis.

The PDA cultures of strain W10 were further incubated at $20^{\circ} \mathrm{C}$ for another 10 days for

production of pycnidia and pycnidiospores (conidia), which were harvested by washing with sterilized water. Conidial concentration was measured using a hemocytometer. The master conidial suspension $\left(\sim 1 \times 10^{7}\right.$ conidia/mL) was 10 -fold diluted with sterilized water to generate serial conidial suspensions with the final concentrations at $2 \times 10^{5}, 2 \times 10^{4}, 2 \times 10^{3}$, $2 \times 10^{2}$ and 20 conidia/mL, and an aliquot of $100 \mu \mathrm{L}$ of each conidial suspension was pippeted to an Eppendorf tube containing $50 \mu \mathrm{L} 3 \times \mathrm{TE}$ buffer. The conidial suspensions in the tubes were heat-treated in water bath $\left(95^{\circ} \mathrm{C}, 2 \mathrm{~min}\right)$, and after that, they were centrifuged at $12,000 \mathrm{rpm}$, and $1 \mu \mathrm{L}$ supernatant of each sample was added to the LAMP mixture. For the control, $1 \mu \mathrm{L}$ sterilized water was added to a LAMP mixture. The LAMP reactions were performed at $65^{\circ} \mathrm{C}$ for $40 \mathrm{~min}$, visualized with SYBR Green I and confirmed by agarose gel electrophoresis.

LAMP-assisted disease diagnosis. Diseased leaves, stems, mature pods and seeds of the winter-type oilseed rape (B. napus cultivar 'Zhongshuang No. 9') showing typical blackleg symptoms (Figure S3) were collected in the 2018-2019 season from a field in Shenshan Town of Chibi County, Hubei Province of China (2952'50"N, 114²3'48"E, $40 \mathrm{~m}$ high above sea level). Leaf samples were collected at the early flowering stage, and samples of stems, pods and seeds were collected at the harvest stage. The pathogen for the blackleg disease of oilseed rape and cruciferous vegetables in that area is L. biglobosa 'brassicae' according to the two-year surveys in our lab (Li 2019). Meanwhile, healthy leaves, stems, mature pods and seeds were collected and used as controls. Tissues were carefully taken from the collected samples using a sharp razor blade, tissue pieces $(\sim 5 \times 5 \mathrm{~mm}$, length $\times$ width $)$ were cut off from the leaves and the pod hulls, stem tissues $(\sim 5 \times 5 \mathrm{~mm}$, length $\times$ width $)$ were peeled off from the epidermal layer of the stems. The diseased leaf, stem and pod-hull pieces, 
or the diseased seeds were separately put in 1.5-mL Eppendorf tubes at 1,2 or 3 pieces (or seeds) in each tube. Meanwhile, two healthy tissue pieces or healthy seeds were put in other Eppendorf tubes as controls. Aliquots of $\mathrm{NaOH}$ solution $(0.4 \mathrm{~mol} / \mathrm{L})$ were added to the tubes, $100 \mu \mathrm{L}$ per tube, and the plant tissue pieces or the seeds were squashed using sterilized plastic pestles, followed by heat-treatment in water bath at $95^{\circ} \mathrm{C}$ for $2 \mathrm{~min}$. Then, the mixtures were centrifuged at $12,000 \mathrm{rpm}$, and $1 \mu \mathrm{L}$ supernatant of each sample was added to a LAMP mixture as DNA template. The LAMP reactions were performed at $65^{\circ} \mathrm{C}$ for $40 \mathrm{~min}$ and visualized with SYBR Green I and confirmed by agarose gel electrophoresis.

\section{Results}

LAMP primers. Results of the RAPD assays showed that among the 20 tested 10-mer Operon primers (Table S1), OPA-19 persistently produced polymorphic DNA fragments among L. biglobosa 'brassicae', L. biglobosa 'canadensis', L. maculans and Phoma macrostoma (Fig. 1A). Strains Lb731 and W10 of L. biglobosa 'brassicae' showed an identical DNA-banding pattern, which differed greatly from those in L. biglobosa 'canadensis' 17-4, L. maculans 2010510-1, and P. macrostoma P2. A DNA fragment of 615 bp in size from L. biglobosa 'brassicae' W10 was selected as target (Figure S1). It was uploaded into the on-line software PrimerExplorer V5 and six primers (forward and backward outer primers F3/B3, inner primers FIP/BIP, and loop primers LF/LB) were designed based on the 230-bp-long central region in that DNA sequence (Fig. 1B, C; Table 2).

LAMP optimization. In the assay for testing the LAMP amplification efficiency $\left(65^{\circ} \mathrm{C}\right.$, $50 \mathrm{~min}$ ), the control reaction mixture without any DNA templates retained a brown coloration in the presence of SYBR Green I, and did not produce any multiple DNA bands patterns when visualized on the agarose gel (Fig. 2A). However, the reaction mixture containing the DNA from strain W10 of L. biglobosa 'brassicae' exhibited a green coloration in presence of 
302 SYBR Green I, and it produced a multiple DNA bands pattern on the agarose gel. This result suggests that the LAMP primers can efficiently amplify the DNA of L. biglobosa 'brassicae' strain W10.

The temperature and time duration required for LAMP detection of L. biglobosa 'brassicae' were optimized. In the temperature assay (40 min), a significant difference in the color of the reaction mixtures amended with SYBR Green I was observed among the temperature treatments ranging from $53^{\circ} \mathrm{C}$ to $75^{\circ} \mathrm{C}$ (Fig. 2B). In two low temperature treatments $\left(53^{\circ} \mathrm{C}, 55^{\circ} \mathrm{C}\right)$ and two high temperature treatments $\left(73^{\circ} \mathrm{C}\right.$ and $\left.75^{\circ} \mathrm{C}\right)$, the reaction mixtures retained a brown coloration without formation of multiple DNA bands patterns in agarose gels after electrophoresis, indicating no detectable LAMP amplifications in these four treatments. In the treatments at $57^{\circ} \mathrm{C}, 59^{\circ} \mathrm{C}, 63^{\circ} \mathrm{C}$ and $65^{\circ} \mathrm{C}$, the reaction mixtures had a green coloration and formed multiple DNA bands patterns in agarose gels after electrophoresis, moreover, the intensity of the green color showed an increase tendency with the temperatures increasing from $57^{\circ} \mathrm{C}$ to $65^{\circ} \mathrm{C}$. In the treatments at $67^{\circ} \mathrm{C}, 69^{\circ} \mathrm{C}$ and $71^{\circ} \mathrm{C}$, the reaction mixtures also showed a green coloration and formed multiple DNA bands patterns in agarose gels after electrophoresis, however, the intensity of the green color showed a decreased tendency with the temperatures increasing from $67^{\circ} \mathrm{C}$ to $71^{\circ} \mathrm{C}$. Therefore, the optimum temperature for LAMP detection of L. biglobosa 'brassicae' W10 was $65^{\circ} \mathrm{C}$. In the time duration assay $\left(65^{\circ} \mathrm{C}\right)$, the LAMP mixtures amended with SYBR Green I retained a brown coloration at $10 \mathrm{~min}$ post reaction $(\mathrm{mpr})$. The color of the reaction mixtures turned green when the time duration lasted between 20 and $80 \mathrm{mpr}$ (Fig. 2B). With the time duration extending to 20,30 and $40 \mathrm{mpr}$, the intensity of the green color gradually increased. The green color intensity had no visible change at the time duration longer than $50 \mathrm{mpr}$, suggesting that the LAMP reactions at 50 to $80 \mathrm{mpr}$ may reach a plateau state. Therefore, the minimum time duration for LAMP detection of L. biglobosa 'brassicae' strain W10 was 40 
$\min$.

LAMP specificity. Results of the specificity assay showed that DNA from 45 fungi exhibited two different effects on LAMP amplification (Table 1). The reaction mixtures with the DNA from 26 strains of L. biglobosa 'brassicae' had a green coloration in the presence of SYBR Green I and formed multiple DNA bands patterns in agarose gels after electrophoresis. This result indicated that these reactions had a positive LAMP amplification. In contrast, the reaction mixtures with the DNA from 19 other fungi, including two close relatives of $L$. biglobosa 'brassicae' (L. biglobosa 'canadensis', L. maculans), three pathogens of oilseed rape (B. cinerea, Co. higginsianum, S. sclerotiorum), and seven saprobes living on oilseed rape (A. alternatae, Ch. globosum, Phoma spp.) retained a brown coloration and did not produce any multiple DNA bands patterns in agarose gels after electrophoresis. This result indicated that these LAMP reactions had a negative LAMP amplification. Therefore, the LAMP detection has a high specificity for L. biglobosa 'brassicae'.

LAMP sensitivity. Results of the sensitivity assay showed that the amount of the template DNA of L. biglobosa 'brassicae' in the reaction mixtures greatly affected LAMP amplification. The reaction mixtures with the amount of DNA per reaction ranging from 132 ng to $132 \mathrm{fg}$ had a green coloration in presence of SYBR Green I (Fig. 3A), and formed multiple DNA bands patterns in electrophored agarose gels (Fig. 3B). In contrast, the reaction mixtures with the amount of DNA per reaction at $13.2 \mathrm{fg}$ and $1.32 \mathrm{fg}$ and the control mixture without the template DNA retained a brown coloration in presence of SYBR Green I (Fig. 3A), and did not produce any multiple DNA bands patterns in the electrophored agarose gels (Fig. 3B). This result suggests that the minimum amount of the DNA in LAMP detection of $L$. biglobosa 'brassicae' is $132 \mathrm{fg}$ per reaction.

Results of the conventional PCR with the primers F3 and B3 (Table 2) indicated that after reaction, the PCR mixtures with the amount of the DNA template per reaction at $132 \mathrm{ng}$, 
$35213.2 \mathrm{ng}, 1.32 \mathrm{ng}$ or $132 \mathrm{pg}$ produced a DNA fragment with the expected size of $210 \mathrm{bp}$ (Fig.

3C). The brightness of the DNA band gradually became weaker with the amount of the DNA per reaction decreasing from $132 \mathrm{ng}$ to $132 \mathrm{pg}$. However, the PCR mixtures with the amount of the DNA template per reaction ranging from $13.2 \mathrm{pg}$ to $1.32 \mathrm{fg}$ did not produce any multiple DNA bands patterns in that agarose gel (Fig. 3C). Therefore, the LAMP detection appears 1000 times more sensitive than the PCR detection.

LAMP-assisted detection of $\boldsymbol{L}$. biglobosa 'brassicae'. The DNA from the mycelia and conidia of L. biglobosa 'brassicae' strain W10 was used as template in LAMP assays. The reaction mixtures containing the DNA from all the three mycelial samples and from 20 to 20000 conidia had a green coloration in the presence of SYBR Green I and produced multiple DNA bands patterns in electrophored agarose gels, indicating positive LAMP amplifications in these reactions (Table 3). In contrast, the control reaction mixtures without the DNA template and the reaction mixture containing the DNA from 2 conidia did not showed any visible color change in the presence of SYBR Green I and formation of multiple DNA bands patterns in the electrophored agarose gel was not observed at all (Table 3), indicating negative LAMP amplifications in these reactions.

LAMP-assisted diagnosis of the blackleg disease. The DNA from healthy and diseased tissues from leaves, stems, pods and seeds of oilseed rape (Figure S3) was used as template in LAMP assays. The results showed that the control mixtures containing the DNA from healthy leaves, stems, pods and seeds displayed a brown coloration in presence of SYBR Green I and did not produce any multiple DNA bands patterns in the agarose gels (Table 3), indicating negative LAMP amplifications in these reactions. However, the reaction mixtures containing the DNA from diseased leaves, stems, pods and seeds displayed a green coloration in presence of SYBR Green I (Table 3) and produced multiple DNA bands patterns on the agarose gels, indicating positive LAMP amplifications in these reactions. 


\section{Discussion}

This study developed a rapid, specific and sensitive LAMP assay for detection of $L$. biglobosa 'brassicae'. The use of LAMP as a tool to study the changing populations of $L$. maculans and L. biglobosa in diseased tissues of oilseed rape as well as in air samples was first reported in 2013 (Jedryczka et al. 2013). However, it is not clear what DNA sequence was used for designing of the LAMP primer set in that study (Jedryczka et al. 2013). In later studies, the internal transcribed spacer regions of the ribosomal DNA (ITS-rDNA) in $L$. maculans and L. biglobosa were used for designing the LAMP primer sets (Zhou et al. 2016; Long et al. 2017; Du et al. 2020). The resulting LAMP assays displayed a consistent detection of these two closely related pathogens (Zhou et al. 2016; Long et al. 2017; Du et al. 2020). However, whether these LAMP assays have specificity for subclades of L. maculans and L. biglobosa remains unknown. Omer and Wallenhammar (2020) reported real-time LAMP detection of L. maculans and L. biglobosa "brassicae". The primer sets SirP and PKS5 for L. maculans were designed based on the nucleotide sequences of the phytotoxin sirodesmin PL gene (sirP) and the polyketide synthase gene (PKS5). respectively, and the primer set PKS5 for L. biglobosa "brassicae" was designed based on the nucleotide sequences of the L. biglobosa "brassicae" PKS21 gene (Omer and Wallenhammar, 2020). In the present study, a 615-bp DNA sequence derived from a RAPD assay was used for designing the LAMP primer set. The resulting LAMP assay showed a positive detection of $L$. biglobosa 'brassicae', but failed to detect L. biglobosa 'canadensis' and L. maculans. Therefore, the LAMP assay has a high specificity for L. biglobosa 'brassicae'. To the best of our knowledge, this is the first report about LAMP detection of $L$. biglobosa at the subclade level. The specificity may lie in the target DNA sequence, which is highly identical among strains of L. biglobosa 'brassicae', as it is a part of the genome of $L$. biglobosa 'brassicae' itself. However, the target DNA sequence has a low identity level 
$402(88.13 \%)$ to that in strains of L. biglobosa 'canadensis'. Moreover, no homologues to the target DNA sequence were identified in the genome of L. maculans. Future studies are

necessary to characterize the nature and location of the 615-bp DNA sequence in the genome of L. biglobosa 'brassicae' and to determine specificity of the primer set for other subclades of L. biglobosa, including 'americensis', 'australensis', 'erysimii', 'occiaustralensis' and 'thlaspii', which belong to different branches from 'brassicae' and 'canadensis' in the phylogeneties inferred from the combined gene set ITS-rDNA, MAT1-2, actin gene (act) and $\beta$-tublin gene (Tub) as well as whole genomes (Vincenot et al. 2008; Dilmaghani et al. 2009; Grandaubert et al. 2014; Zou et al. 2019).

Previous studies indicated that the majority of the target DNA sequences used in the LAMP assays for fungi, yeasts and oomycetes are selected from public databases (Niessen 2015). The target DNA sequences include the ribosomal RNA genes in most cases, as well as many nuclear genes such as acll, amyl, btub, cap59, gaoA, gp43, rodA, tefl, and ypt1 (Endo et al. 2004; Locas et al. 2010; Matsuzawa et al. 2010; Niessen and Vogel 2010; Huang et al. 2011; Luo et al. 2012; Niessen et al. 2012; Chen et al. 2013; Ferdousi et al. 2014; Niessen 2015). Meanwhile, quite a few previous studies reported use of RAPD assays to explore some novel DNA sequences as targets for LAMP detection of Verticillium dahliae, Fusarium oxysporum f.sp. cubense race 4, F. oxysporum f.sp. niveum and F. mangiferae (Li et al. 2013; Moradi et al. 2013; Peng et al. 2013; Pu et al. 2014). The present study selected a 615-bp-long RAPD sequence of L. biglobosa 'brassicae' as target in the LAMP assay for $L$. biglobosa 'brassicae'. The result corroborated the previous studies mentioned above that combined use of RAPD and LAMP is a valid strategy to develop the molecular techniques for detection and discrimination of the closely related plant pathogenic fungi.

The LAMP assay developed in this study provided a simple, rapid and efficient tool to diagnose the blackleg disease caused by L. biglobosa 'brassicae', and to assist identification 
427 of isolates of L. biglobosa 'brassicae'. Previous studies demonstrated that L. biglobosa 428 'brassicae' usually co-exists with L. maculans, L. biglobosa 'canadensis' and other minor 429 subclades of L. biglobosa (e.g. 'americensis', 'australensis' and 'occiaustralensis') (Voigt et 430 al, 2005; Fitt et al. 2006a; Vincenot et al. 2008; Dilmaghani et al. 2009; Zou et al. 2019). At 431 present, L. biglobosa 'brassicae' was found to be the sole causal agent for blackleg of oilseed 432 rape and cruciferous vegetables in China (Li et al. 2013; Liu et al. 2014; Cai et al. 2015, 433 2018). However, considering the situation of the continuous imports of seeds of oilseed rape 434 from foreign countries, L. maculans and other subclades of L. biglobosa might be introduced to this country (Fitt et al. 2008; Zhou et al. 2010; Wang et al. 2011; Zhang et al. 2014).

Therefore, it is necessary to persistently monitor the populations of the blackleg pathogens in oilseed rape-plantation areas as well as in the areas surrounding the import ports in China.

This study found that the LAMP assay could consistently detect the DNA extracted from the pure cultures of L. biglobosa 'brassicae' and from diseased plant tissues using the simplified DNA extraction methods (e.g. TE-buffer or alkaline lysis under $95^{\circ} \mathrm{C}$ for $2 \mathrm{~min}$ ), and the LAMP assay was performed within $2 \mathrm{~h}$. Using this technique together with the LAMP assays for L. maculans and L. biglobosa developed in previous studies (Zhou et al. 2016; Long et al. 2017; Du et al. 2020), it is possible to conduct a large-scale identification of the isolates of Leptosphaeria spp. and to carry out the on-site diagnosis of the blackleg disease in field surveys. Future studies are required to assemble the LAMP components into a kit and to optimize the LAMP assays under the field conditions.

\section{Acknowledgements}

This research was financially funded by the China Agriculture Research System (Grant CARS-12). We appreciate kind help from Dr. Zhenhua Wang of the Technical Center of the Wuhan Customs (Wuhan, China), and Dr. Jianping Yi of the Technical Center of the Shanghai Customs (Shanghai, China) for providing strains of L. biglobosa 'canadensis' and $L$. 
452 maculans.

\section{$453 \quad$ Literature cited}

454 Cai, X., Zhang, J., Wu, M. D., Jiang, D. H., Li, G. Q., and Yang, L. 2015. Effect of water 455 flooding on survival of Leptosphaeria biglobosa 'brassicae' in stubble of oilseed rape 456 (Brassica napus) in central China. Plant Dis. 99:1426-1433.

457 Cai, X., Huang, Y. J., Jiang, D. H., Fitt, B. D. L., Li, G. Q., and Yang, L. 2018. Evaluation of $458 \quad$ oilseed rape seed yield losses caused by Leptosphaeria biglobosa in central China. Eur. $459 \quad$ J. Plant Pathol. 150:179-190.

460 Chen, G. Y., Wu, C. P., Li, B., Su, H., Zhen, S. Z., and An, Y. L. 2010. Detection of $461 \quad$ Leptosphaeria maculans from imported canola seeds. J. Plant Dis. Protect. 117(4):173-176.

Chen, Q., Huang, F., Liao, F. R., Chen, H. Y., Yi, J. P., and Lin, S. M. 2013. Detection and identification of Leptosphaeria maculans from imported pakchoi (Brassica chinensis L.) seeds. Plant Quarantine 27(4):62-64.

Chigogora, J. L., and Hall, R. 1995. Relationships among measures of blackleg in winter oilseed rape and infection of harvested seed by Leptosphaeria maculans. Can. J. Plant Pathol. 17(1):25-30.

Dilmaghani, A., Balesdent, M. H., Didier, J. P., Wu, C., Davey, J., Barbetti, M. J., Li H., Moreno-Rico, O., Phillips, D., Despeghel, J. P., Vincenot, L., Gout, L., and Rouxel, T. 2009. The Leptosphaeria maculans-Leptosphaeria biglobosa species complex in the American continent. Plant Pathol. 58:1044-1058.

Du, R., Zhang, J., Yang, L., Wu, M. D., and Li, G. Q. 2020. Development of LAMP techniques to detect Leptosphaeria biglobosa and L. maculans in oilseed rape. Acta Phytopathol. Sin. DOI: 10.13926/j.cnki.apps.000514.

Endo, S., Komori, T., Ricci, G., Sano, A., Yokoyama, K., Ohori, A., Kamei, K., Franco, M., 
Miyaji, M., and Nishimura, K. 2004. Detection of gp43 of Paracoccidioides brasiliensis by the loop-mediated isothermal amplification (LAMP) method. FEMS Microbiol. Lett. 234:93-97.

Fan, F., Yin, W. X., Li, G. Q., Yin, L. F., and Luo, C. X. 2018. Development of a LAMP method for detecting SDHI fungicide resistance in Botrytis cinerea. Plant Dis. 102:1612-1618.

Ferdousi, A., Shahhossein, M. H., Bayat, M., Hashimi, S. J., and Gharhi, M. 2014. Comparison of polymerase chain reaction and loop-mediated isothermal amplification for diagnosis of Fusarium solani in human immunodeficiency virus positive patients. Afri. J. Biotechnol. 13:1496-1502.

Fitt, B. D. L., Huang, Y. J., van den Bosch, F., and West, J. S. 2006a. Coexistence of related pathogen species on arable crops in space and time. Annu. Rev. Phytopathol. 44:163-182.

Fitt, B. D. L., Brun, H., Barbetti, M. J., and Rimmer, S. R. 2006b. World-wide importance of phoma stem canker (Leptosphaeria maculans and L. biglobosa) on oilseed rape (Brassica napus). Eur. J. Plant Pathol. 114:3-15.

Fitt, B. D. L., Hu, B. C., Li, Z. Q., Liu, S. Y., Lange, R. M., Kharbanda, P. D., Butterworth, M. H., and White R. P. 2008. Strategies to prevent spread of Leptosphaeria maculans (phoma stem canker) onto oilseed rape crops in China; costs and benefits. Plant Pathol. $57: 652-664$.

Grandaubert, J., Lowe, R. G., Soyer, J. L., Schoch, C. L., van de Wouw, A. P., Fudal, I., Robbertse, B., Lapalu, N., Links, M. G., Ollivier, B., Linglin, J., Barbe, V., Mangenot, S., Cruaud, C., Borhan, H., Howlett, B. J., Balesdent, M., and Rouxel, T. 2014. Transposable element-assisted evolution and adaptation to host plant within the Leptosphaeria maculans-Leptosphaeria biglobosa species complex of fungal pathogens. 
BMC Genomics 15:891.

Gugel, R. K., and Petrie, G. A. 1992. History, occurrence, impact and control of blackleg of rapeseed. Can. J. Plant Pathol. 14:36-45.

Huang, C., Sun, Z., Yan, J., Luo, Y., Wang, H., and Ma, Z. 2011. Rapid and precise detection of latent infections of wheat stripe rust in wheat leaves using loop-mediated isothermal amplification. J. Phytopathol. 159:582-584.

Jedryczka, M., Burzynski, A., Brachaczek, A., Langwinski, W., Song, P., and Kaczmarek, J. 2013. Loop-mediated isothermal amplification as a good tool to study changing Leptosphaeria populations in oilseed rape plants and air samples. Acta Agrobot. 66:93-99.

Laing, M. D. 1986. The crucifer blackleg pathosystem in Natal, South Africa. Acta Horticult. 194:141-151.

Li, B. J., Du, J. L., Lan, C. Z., Liu, P. Q., Weng, Q. Y., and Chen, Q. H. 2013. Development of a loop-mediated isothermal amplification assay for rapid and sensitive detection of Fusarium oxysporum f.sp. cubense race 4. Eur. J. Plant Pathol. 135:903-911.

Li, J. C. 2019. Fixed-site monitoring of occurrence of blackleg of oilseed rape and characterization of infection by conidia of the pathogen. Master's degree dissertation of Huazhong Agricultural University (Wuhan, China). IV +61pp.

Li, Q. S., Rong, S. B., Hu, B. C., Jiang, Y. F., Hou, S. M., Fei, W. X. Chen, F. X., Wu, X. J., Fan, Z. X. and Lei, W. X. 2013. Distribution of blackleg disease on oilseed rape in China and its pathogen identification. Chin. J. Oil Crop Sci. 35:415-423.

Limonard, T. 1968. Ecological aspects of seed health testing. Proc. Interl. Seed Testing Assoc. 33(3): 64 .

Liu, S. Y., Liu, Z., Fitt, B. D. L., Evans, N., Foster, S. J., Huang, Y. J., Latunde-Dada, A. O., and Lucas, J. A. 2006. Resistance to Leptosphaeria maculans (phoma stem canker) in 
Brassica napus (oilseed rape) induced by L. biglobosa and chemical defense activators in field and controlled environments. Plant Pathology 55(3): 401-412.

Liu, Z., Latunde-Dada, A. O., Hall, A. M., and Fitt, B. D. L. 2014. Phoma stem canker disease on oilseed rape (Brassica napus) in China is caused by Leptosphaeria biglobosa 'brassicae'. Eur. J. Plant Pathol. 140:841-857.

Lob, S., Jaspers, M. V., Ridgway, H. J., and Jones, E. E. 2013. Leptosphaeria maculans/L. biglobosa disease progression in oilseed rape and timing of ascospore release under New Zealand conditions. New Zealand Plant Protect. 66:214-222.

Long, Y., Ma, X. H., Yuan, J. J., Lu, N. H., Yang, Z. Y., Wei, S. and Wang, W. F. 2017. Establishment of LAMP-HNB method for detection of Leptosphaeria maculans in rape. Guangdon Agri. Sci. 44:66-69.

Lucas, S., da Luz Martins, M., Flores, O., Meyer, W., Spencer-Martins, I., and Ina, J. 2010. Differentiation of Cryptococcus neoformans varieties and Cryptococcus gattii using CAP59-based loop-mediated isothermal DNA amplification. Clin. Microbiol. Infect. $16: 711-714$.

Luo, J., Vogel, R. F., and Niessen, L. 2012. Development and application of a loop-mediated isothermal amlification assay for rapid identification of aflatoxinogenic molds and their detection in food samples. Interl. J. Food Microbiol. 159:214-224.

Matsuzawa, T., Tanaka, R., Horie, Y., Gonoi, T., and Yaguchi, T. 2010. Development of rapid and specific molecular discrimination methods for pathogenic Emericella species. Japn. J. Med. Mycol. 51:109-115.

Mendes-Pereira, E., Balesdent, M., Brun, H., and Rouxel, T. 2003. Molecular phylogeny of the Leptosphaeria maculans-L. biglobosa species complex. Mycol. Res. 107:1287-1304.

Molina, J. P. E., Escande, A., Cendoya, G., and Quiroz, F. 2017. Qualitative and quantitative 
552 553

554

factors affecting the relationship between canola leaf spot epidemic and stem base canker (Leptosphaeria maculans) in Argentina. Australasian Plant Pathol. 46:453-461.

Möller, E. M., Bahnweg, G., Sandermann, H., and Geige, H. H. 1992. A simple and efficient protocol for isolation of high molecular weight DNA from filamentous fungi, fruit bodies, and infected plant tissues. Nucl. Acids Res. 20:6115-6116.

Moradi, A., Almasi, M.A., Jafary, H., and Mercado-Blanco, J. 2013. A novel and rapid loop-mediated isothermal amplification assay for the specific detection of Verticillium dahliae. J. Appl. Microbiol. 116:942-954.

Niessen, L., and Vogel, R. F. 2010. Detection of Fusarium graminearum DNA using a loop-mediated isothermal amplification (LAMP) assay. Interl. J. Food Microbiol. 140:183-191.

Niessen, L., Gräfenhan, T., and Vogel, R. F. 2012. ATP citrate lyase 1 ( acll) gene based loop-mediated amplification assay for the detection of the Fusarium tricinctum species complex in pure cultures and in cereal samples. Interl. J. Food Microbiol. 158:171-185.

Niessen, L. 2015. Current state and future perspectives of loop-mediated isothermal amplification (LAMP)-based diagnosis of filamentous fungi and yeasts. Appl. Microbiol. Biotechnol. 99:553-574.

Notomi, T., Okayama, H., Masubuchi, H., Yonekawa, T., Watanabe, K., Amino, N., and Hase, T. 2000. Loop-mediated isothermal amplification of DNA. Nucl. Acids Res. 28:e63.

Omer, Z. S., and Wallenhammar, A. -C. 2020. Development of loop-mediated isothermal amplification assays for rapid detection of blackleg pathogens in Swedish winter oil seed rape. Eur. J. Plant Pathol. 157:353-365.

Peng, J., Zhan, Y. F., Zeng F. Y., Long, H. B., Pei, Y. L., and Guo, J. R. 2013. Development of a real-time fluorescence loop-mediated isothermal amplification assay for rapid and 

quantitative detection of Fusarium oxysporum f.sp. niveum in soil. FEMS Microbiol. Lett. 349:127-134.

Piening, L., Okolo, E., and Harder, D. 1975. Blackleg of rapeseed in Kenya. East Afr. Agri. For. J. 41:110-113.

Plummer, K. M., Dunse, K., and Howlett, B. J. 1994. Non-aggressive strains of the blackleg fungus, Leptosphaeria maculans, are present in Australia and can be distinguished from aggressive strains by molecular analysis. Aus. J. Bot. 42:1-8.

Pu, J. J., Xie, Y. X., Zhang, H., Zhang, X., Qi, Y. X., and Peng, J. 2014. Development of a real-time fluorescence loop-mediated isothermal amplification assay for rapid and quantitative detection of Fusarium mangiferae associated with mango malformation. Physiol. Mol. Plant Pathol. 86:81-88.

Rong, S. B., Hu, B. C., Chen, F. X., Wu, X. J. Hou, S. M., Fei, W. X., and Li, Q. S. 2015. Effects of Leptosphaeria biglobosa on seed yield and related traits of oilseed rape. Crops (6):159-161.

Salisbury, P. A., Ballinger, D. J., Wratten, N., Plummer, K. M., and Howlett, B. J. 1995. Blackleg disease on oilseed Brassica in Australia: a review. Aus. J. Exper. Agri. 35:665-672.

Shoemaker, R. A., and Brun, H. 2001. The teleomorph of the weakly aggressive segregate of Leptosphaeria maculans. Can. J. Bot. 79:412-419.

Vincenot, L., Balesdent, M. H., Li, H., Barbetti, M. J., Sivasithamparam, K., Gout, L., and Rouxel, T. 2008. Occurrence of a new subclade of Leptosphaeria biglobosa in Western Australia. Phytopathology 98:321-329.

van de Wouw, A. P., Thomas, V. L., Cozijnsen, A. J., Marcroft, S. J., Salisbury, P. A., and Howlett, B. J. 2008. Identification of Leptosphaeria biglobosa 'canadensis' on Brassica juncea stubble from northern New South Wales, Australia. Australasian Plant Dis. Notes 
602 603 604 3:124-128.

Voigt, K., Cozijnsen, A. J., Kroymann, J., Pöggeler, S., and Howlett, B. J. 2005. Phylogenetic relationships between members of the crucifer pathogenic Leptosphaeria maculans species complex as shown by mating type (MAT1-2), actin, and $\beta$-tubulin sequences. Mol. Phylogen. Evol. 37:541-557.

Wang, T., Wang, C. N., Zhang, H., Wen, J. J., and Zhang, B. 2017. Study on rapid extraction of genomic DNA from Chinese cabbage. Acta Agri. Boreali-Sin. 32:67-72.

Wang, G. P., Hu, K. L., and Jedryczka, M. 2003. Health testing and evaluation of Leptosphaeria maculans (Phoma lingam) contamination in Brassica napus seed samples from Poland and England. J. South China Agri. Univ. (Nat. Sci. Ed.) 24(4):28-31.

Wang, Z. H., Yang, W., Zhao, H., Zeng, X. D., Li, F. X., Cai, X., Wang, H. C., and Yu, H. 2011. Detection and identification of Leptosphaeria maculans in imported Canadian rapeseeds. J. Huazhong Agri. Univ. 30(1):66-69.

West, J. S., Evans, N., Liu, S., Hu, B., and Peng, L. 2000. Leptosphaeria maculans causing stem canker of oilseed rape in China. Plant Pathol. 49:800.

West, J. S., Kharbanda, P., Barbetti, M. J., and Fitt, B. D. L. 2001. Epidemiology and management of Leptosphaeria maculans (phoma stem canker) in Australia, Canada and Europe. Plant Pathol. 50:10-27.

Williams, R. H., and Fitt, B. D. L. 1999. Differentiating A and B groups of Leptosphaeria maculans, causal agent of stem canker (blackleg) of oilseed rape. Plant Pathol. $48: 161-175$.

Zhang, X., White, R. P., Demir, E., Jedryczkae, M., Lange, R. M., Islam, M., Li, Z. Q., Huang, Y. J., Hall, A. M., Zhou, G., Wang, Z., Cai, X., Skelsey, P., and Fitt, B. D. L. 2014. Leptosphaeria spp., phoma stem canker and potential spread of L. maculans on oilseed rape crops in China. Plant Pathol. 63:598-612. 
627 Zhao, H., Wang, Z. H., Zeng, X. D., Yi, J. P., Li, B., Li,G. Q., Wu, P. S., and Cai, X. 2015.

628

629

630

631

632

633

634

635

636

637

638

639 Detection and identification of Plenodomus biglobosus. GB/T 31798-2015. Released by General Administration of Quality Supervision, Inspection and Quarantine of the People's Republic of China, and China National Standardizing Committee.

Zhou, G. L., Shang, L. L., Yu, C., Yin, L. P., Xu, D. S., and Yi, J. P. 2010. Detection of Leptosphaeria maculans and L. biglobosa in oilseed rape samples imported from Australia. Acta Phytophyl. Sin. 37(4):289-294.

Zhou, Y., Huang, H. L., Li, X. J., Shan, C. L., Li, X. S., Chen, Y., Shao, W. D., and Zhu, P. 2016. Establishment of Leptosphaeria maculans detection by loop-mediated isothermal amplification combined with a lateral-flow dipstick. Plant Quarantine 30(4):32-37.

Zou, Z. W., Zhang, X. H., Parks, P., du Toit, L. J., van de Wouw, A. P., and Fernando W. G. D. 2019. A new subclade of Leptosphaeria biglobosa identified from Brassica rapa. Interl. J. Mol. Sci. 20:1668. 
Table 1. Fungal strains from oilseed rape (Brassica napus), their origin and the LAMP detection results

\begin{tabular}{|c|c|c|c|c|}
\hline \multirow[b]{2}{*}{ Strain } & \multirow[b]{2}{*}{ Species } & \multirow[b]{2}{*}{ Origin (location and year) } & \multicolumn{2}{|c|}{ LAMP result } \\
\hline & & & SYBR green $I^{x}$ & $\begin{array}{l}\text { Multiple DNA } \\
\text { bands patterns y }\end{array}$ \\
\hline W10 & L. biglobosa 'brassicae' & Wuxue, Hubei, China, 2011 & + & + \\
\hline $\mathrm{Lb} 22$ & L. biglobosa 'brassicae' & Wuhan, Hubei, China, 2017 & + & + \\
\hline Lb23 & L. biglobosa 'brassicae' & Wuhan, Hubei, China, 2017 & + & + \\
\hline Lb219 & L. biglobosa 'brassicae' & Macheng City, Hubei, China, 2017 & + & + \\
\hline Lb220 & L. biglobosa 'brassicae' & Macheng City, Hubei, China, 2017 & + & + \\
\hline Lb221 & L. biglobosa 'brassicae' & Macheng City, Hubei, China, 2017 & + & + \\
\hline Lb324 & L. biglobosa 'brassicae' & Xiangyang City, Hubei, China, 2017 & + & + \\
\hline Lb325 & L. biglobosa 'brassicae' & Xiangyang City, Hubei, China, 2017 & + & + \\
\hline Lb326 & L. biglobosa 'brassicae' & Xiangyang City, Hubei, China, 2017 & + & + \\
\hline Lb460 & L. biglobosa 'brassicae' & Badong County, Hubei, China, 2017 & + & + \\
\hline Lb463 & L. biglobosa 'brassicae' & Badong County, Hubei, China, 2017 & + & + \\
\hline Lb649 & L. biglobosa 'brassicae' & Nanjing City, Jiangsu, China, 2017 & + & + \\
\hline $\operatorname{Lb} 650$ & L. biglobosa 'brassicae' & Nanjing City, Jiangsu, China, 2017 & + & + \\
\hline Lb691 & L. biglobosa 'brassicae' & Luoping County, Yunnan, China, 2017 & + & + \\
\hline Lb692 & L. biglobosa 'brassicae' & Luoping County, Yunnan, China, 2017 & + & + \\
\hline Lb695 & L. biglobosa 'brassicae' & Luoping County, Yunnan, China, 2017 & + & + \\
\hline Lb716 & L. biglobosa 'brassicae' & Chongzhou County, Sichuan, 2017 & + & + \\
\hline
\end{tabular}




\begin{tabular}{|c|c|c|c|c|}
\hline Lb717 & L. biglobosa 'brassicae' & Chongzhou County, Sichuan, 2017 & + & + \\
\hline $\mathrm{Lb} 718$ & L. biglobosa 'brassicae' & Chongzhou County, Sichuan, 2017 & + & + \\
\hline Lb731 & L. biglobosa 'brassicae' & Xingyang City, Henan, China, 2017 & + & + \\
\hline Lb903 & L. biglobosa 'brassicae' & Guiyang City, Guizhou, 2017 & + & + \\
\hline Lb904 & L. biglobosa 'brassicae' & Guiyang City, Guizhou, 2017 & + & + \\
\hline Lb905 & L. biglobosa 'brassicae' & Guiyang City, Guizhou, 2017 & + & + \\
\hline Lb915 & L. biglobosa 'brassicae' & Guiyang City, Guizhou, 2017 & + & + \\
\hline Lb916 & L. biglobosa 'brassicae' & Guiyang City, Guizhou, 2017 & + & + \\
\hline Lb917 & L. biglobosa 'brassicae' & Guiyang City, Guizhou, 2017 & + & + \\
\hline $17-4$ & L. biglobosa 'canadensis' & Seeds of oilseed rape imported from Canada, 2009 & - & - \\
\hline Lb2700 & L. biglobosa 'canadensis' & Hailar City, Inner Mongolia, China, 2018 & - & - \\
\hline Lb2701 & L. biglobosa 'canadensis' & Hailar City, Inner Mongolia, China, 2018 & - & - \\
\hline Lb2702 & L. biglobosa 'canadensis' & Hailar City, Inner Mongolia, China, 2018 & - & - \\
\hline Lb2703 & L. biglobosa 'canadensis' & Hailar City, Inner Mongolia, China, 2018 & - & - \\
\hline Lb2704 & L. biglobosa 'canadensis' & Hailar City, Inner Mongolia, China, 2018 & - & - \\
\hline Lb2705 & L. biglobosa 'canadensis' & Hailar City, Inner Mongolia, China, 2018 & - & - \\
\hline $2010510-1$ & L. maculans & Seeds of oilseed rape imported from Canada, 2010 & - & - \\
\hline $2010510-2$ & L. maculans & Seeds of oilseed rape imported from Canada, 2010 & - & - \\
\hline $\mathrm{C} 1$ & Colletotrichum higginsianum & Huzhou County, Qinghai, 2017 & - & - \\
\hline CanL-24 & Alternaria alternata & Zhang et al. 2014 & - & - \\
\hline CanS-33 & Chaetomium globosum & Zhang et al. 2014 & - & - \\
\hline
\end{tabular}




\begin{tabular}{llll}
\hline CanS-75 & Botrytis cinerea & Zhang et al. 2014 & - \\
P1 & Phoma sp. & Badong County, Hubei, China, 2017 & - \\
P2 & Phoma macrostoma & Yunxi County, Hubei, China, 2017 & - \\
P3 & Phoma sp. & Yunxi County, Hubei, China, 2017 & - \\
P4 & Phoma glomerata & Huzhou County, Qinghai, 2017 & - \\
P5 & Phoma herbarum & Huzhou County, Qinghai, 2018 & - \\
SS-1 & Sclerotinia sclerotiorum & Wuhan City, Hubei, 2014 & - \\
\hline
\end{tabular}

y SYBR Green I was added to the LAMP mixtures after reaction,+, positive detection; -, negative detection.

${ }^{z}$ The LAMP products were loaded in $1 \%$ agarose gels and after electrophoresis, the gels were stained with a ethidium bromide solution and observed under an UV-illuminator. +, with multiple DNA bands patterns (DNA ladder patterns); -, without multiple DNA bands patterns. 
Table 2. The nucleotide sequences of the six LAMP primers for L. biglobosa 'brassicae'

\begin{tabular}{ll}
\hline Primer & Oligonucleotide sequence (5' to 3') \\
\hline Forward outer primer F3 & GTATTGGCCGCGAATTCC \\
Backward outer primer B3 & GGAGATTGGCCACTATGG \\
Forward inner primer FIP (F1c-F2) & GGCGTCTCTTTTATGGCTATTTTCT-GGTCAAAAGTTGTTTGGA \\
Backward inner primer BIP (B1c-B2) & AATGTCAGGAAGTCTGAAAAGCT-ACGTTCTCTGATCAGGAC \\
Forward loop primer LF & CCGAAATGAATTGTACCAGTATCCT \\
Backward loop primer LB & ACTGCCTCATGCAACATGG \\
\hline
\end{tabular}


Table 3. LAMP detection of L. biglobosa 'brassicae' in pure cultures and plant tissues of oilseed rape (stems, leaves, pods and seeds).

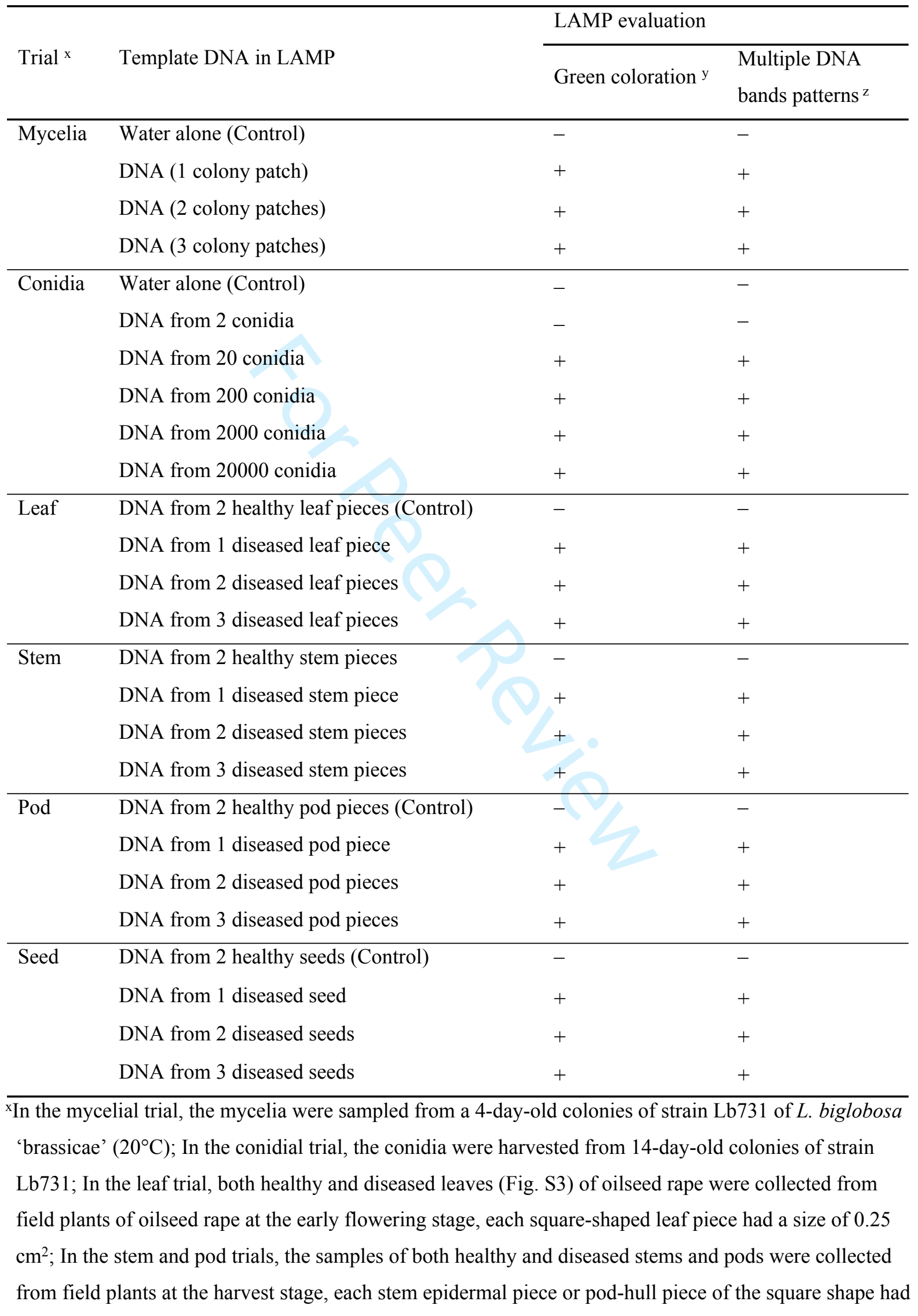


a size of $0.25 \mathrm{~cm}^{2}$; In the seed trial, healthy seeds were collected from healthy pods of field plants of oilseed rape at the harvest stage, diseased seeds were collected from diseased pods of field plants of oilseed rape also at the harvest stage. The TE buffer-lysis method was used to extract the DNA from the sampled mycelia and conidia in the mycelial and conidia trials. The alkaline-lysis method was used to extract DNA from sampled tissues of leaves, stems, pods and seeds in the leaf, stem, pod and seed trials. ${ }^{y}$ SYBR Green I was added to the LAMP mixtures after reaction, +, positive amplification; -, negative amplification.

${ }^{z}$ The LAMP products were loaded in $1 \%$ agarose gels and after electrophoresis, the gels were stained with a ethidium bromide solution and observed under an UV-illuminator. +, with multiple DNA bands patterns; -, without multiple DNA bands patterns. 
A

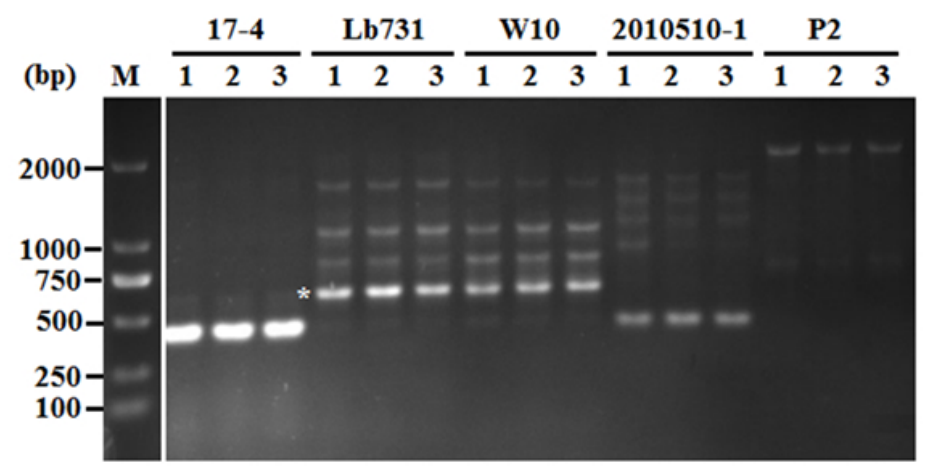

B

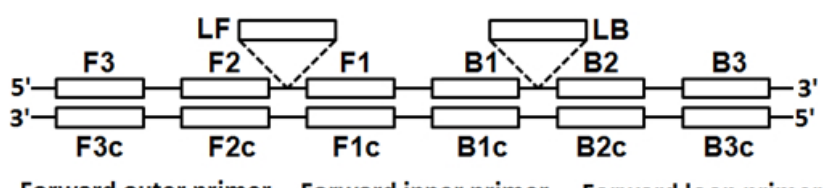

Forward outer primer Forward inner primer Forward loop primer
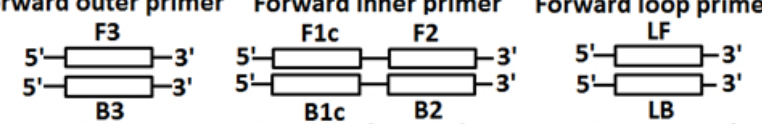

Backward outer primer Backward inner primer Backward loop primer
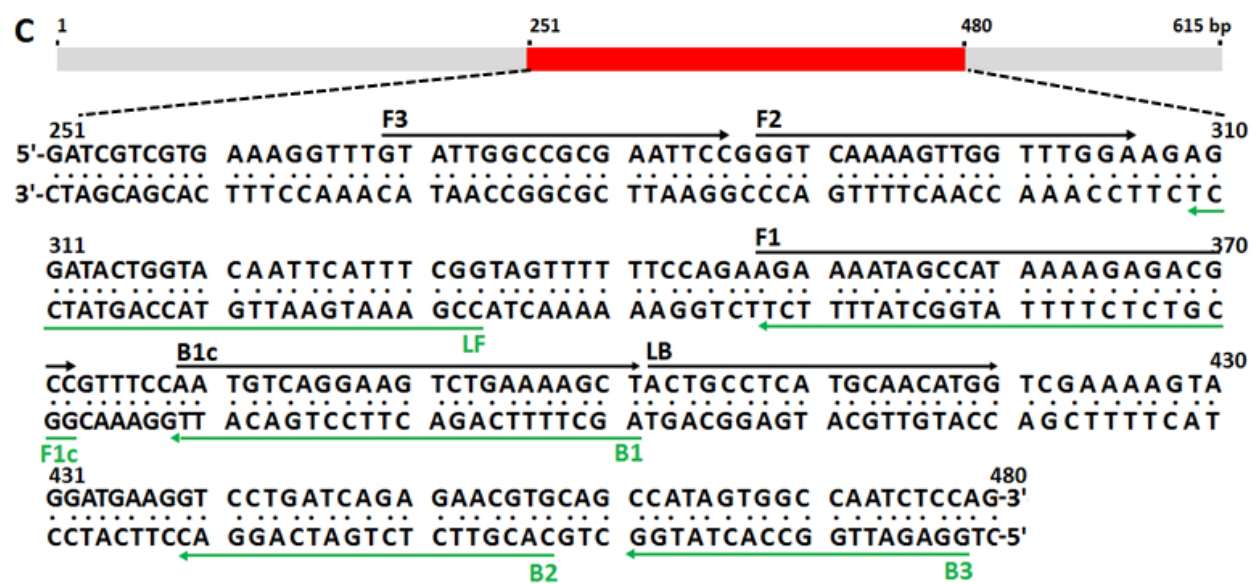

Figure 1. Designing of the LAMP primers for detection of L. biglobosa 'brassicae'. A, An agarose gel electrophoregram showing the polymorphic DNA fragments among different fungal species ( $L$. biglobosa 'canadensis' 17-4, L. biglobosa 'brassicae' Lb731 and W10, L. maculans 2010510-5, and P. macrostoma P2) from the RAPD assay with the primer OPA-19. M, DNA marker; *, the DNA fragment was purified, cloned and sequenced for designing of the LAMP primers; B, A schematic diagram showing location of the LAMP primers in the target DNA sequence; \%"C, Top, a schematic diagram showing location of the 230-bp-long region within the 615-bp DNA sequence from the RAPD assay; Bottom, location of the LAMP primers in the 230-bp-long double-stranded DNA region. Arrows indicate the direction of the primers initiating amplification. 


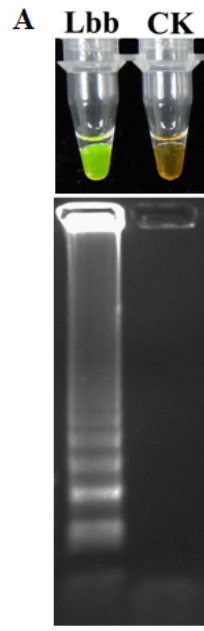

B Temperature (40 min)

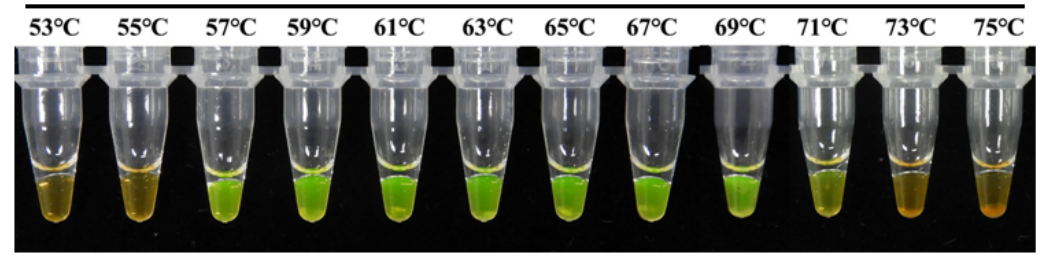

C

Duration for LAMP at $65^{\circ} \mathrm{C}$

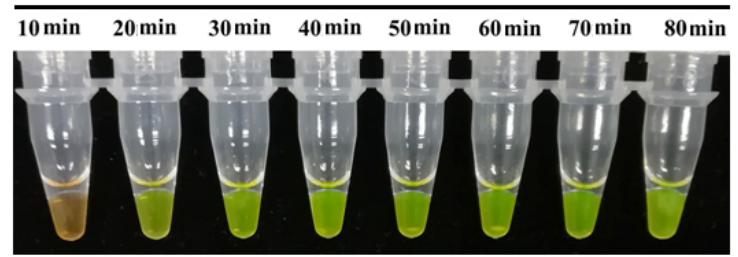

Figure 2. Optimization of the temperature and the time duration for LAMP detection of L. biglobosa 'brassicae'. A, Top, two LAMP reaction mixtures with different colors in the presence of SYBR Green I, green in the reaction with DNA from strain W10 of L. biglobosa 'brassicae' (Lbb) as template, whereas brown in the control (CK) reaction mixture without DNA template; Bottom, an agarose gel electrophoregram showing difference of the two reaction mixtures in formation of a multiple DNA bands pattern on the agarose gel; B, Twelve LAMP reactions under different temperatures showing different colors in presence of SYBR Green I; C, Eight LAMP reactions with different time durations showing different colors in presence of SYBR Green I. 
A

Figure 3. Effect of the amount of template DNA on LAMP and PCR detection of L. biglobosa 'brassicae'. A, Ten LAMP reactions with different amounts of the template DNA from strain W10 of L. biglobosa 'brassicae' showing different colors in the presence of SYPR Green I. CK, control reaction mixture without DNA template; B, An agarose gel electrophoregram showing a difference among the reaction mixtures in formation of multiple DNA bands patterns on the agarose gel; C, An agarose gel electrophoregram showing the 210-bp-long DNA bands from the PCR reactions containing different amounts of template DNA from $L$. biglobosa 'brassicae' W10. 
Table S1. Operon primers used in RAPD assays of this study.

\begin{tabular}{|c|c|c|c|}
\hline \multirow[b]{2}{*}{ Primer } & \multirow[b]{2}{*}{ Sequence (5' to $3^{\prime}$ ) } & \multicolumn{2}{|c|}{ Efficacy in RAPD } \\
\hline & & $\begin{array}{l}\text { Persistency in amplification } \\
\text { of L. biglobosa 'brassicae' y }\end{array}$ & $\begin{array}{c}\text { \#DNA bands for L. biglobosa } \\
\text { 'brassicae' }{ }^{\text {z }}\end{array}$ \\
\hline OPA-02 & TGCCGAGCTG & $2 / 3$ & 0 \\
\hline OPA-07 & GAAACGGGTG & $1 / 3$ & 0 \\
\hline OPA-13 & CAGCACCCAC & $2 / 3$ & 0 \\
\hline OPA-15 & TTCCGAACCC & $2 / 3$ & 0 \\
\hline OPA-19 & CAAACGTCGG & $3 / 3$ & 1 \\
\hline OPB-01 & GTTTCGCTCC & $2 / 3$ & 0 \\
\hline OPB-06 & TGCTCTGCCC & $3 / 3$ & 0 \\
\hline OPB-11 & GTAGACCCGT & $2 / 3$ & 0 \\
\hline OPB-20 & GGACCCTTAC & $2 / 3$ & 0 \\
\hline OPC-04 & CCGCATCTAC & $3 / 3$ & 0 \\
\hline OPC-12 & TGTCATCCCC & $3 / 3$ & 0 \\
\hline OPE-02 & GGTGCGGGAA & $1 / 3$ & 0 \\
\hline OPE-11 & GAGTCTCAGG & $2 / 3$ & 0 \\
\hline OPG-14 & GGATGAGACC & $3 / 3$ & 0 \\
\hline OPG-18 & GGCTCATGTG & $1 / 3$ & 0 \\
\hline OPI-08 & TTTGCCCGGT & $1 / 3$ & 0 \\
\hline OPI-12 & AGAGGGCACA & $2 / 3$ & 0 \\
\hline OPR-02 & CACAGCTGCC & $1 / 3$ & 0 \\
\hline OPW-04 & CAGAAGCGGA & $1 / 3$ & 0 \\
\hline OPX-19 & TGGCAAGGCA & $1 / 3$ & 0 \\
\hline
\end{tabular}

${ }^{\mathrm{y}}$ Number of RAPD assays with positive amplification of L. biglobosa 'brassicae'/Total number of the RAPD assays;

zThe selected DNA bands for L. biglobosa 'brassicae' were approximately 600 bp (close to the size of ITS-rDNA) and in agarose gel electrophoresis, the abundance of the DNA bands in the gels was high enough for purification and cloning (e.g., bright DNA bands under the UV-illuminator). 
Table S2. The LAMP reaction system of for detection of L. biglobosa 'brassicae'.

\begin{tabular}{lll}
\hline Composition & Volume & Final concentration \\
\hline $10 \times$ reaction buffer & $2.5 \mu \mathrm{L}$ & $1 \times$ reaction buffer \\
$\mathrm{MgSO}_{4}(100 \mathrm{mmol} / \mathrm{L})$ & $1 \mu \mathrm{L}$ & $4 \mathrm{mmol} / \mathrm{L}$ \\
dNTPs Mix $(10 \mathrm{mmol} / \mathrm{L}$ for each) & $2.5 \mu \mathrm{L}$ & $10 \mathrm{mmol} / \mathrm{L}$ for each $\mathrm{NNTP}$ \\
F3/B3 $(10 \mu \mathrm{mol} / \mathrm{L}$ for each) & $0.5 \mu \mathrm{L}$ & $0.2 \mu \mathrm{mol} / \mathrm{L}$ for each primer \\
FIP/BIP $(10 \mu \mathrm{mol} / \mathrm{L}$ for each) & $4 \mu \mathrm{L}$ & $1.6 \mu \mathrm{mol} / \mathrm{L}$ for each primer \\
LF/LB $(10 \mu \mathrm{mol} / \mathrm{L}$ for each) & $1 \mu \mathrm{L}$ & $0.4 \mu \mathrm{mol} / \mathrm{L}$ for each primer \\
Bst 2.0 WarmStart ${ }^{\circledR}$ DNA polymerase & $1 \mu \mathrm{L}$ & $0.32 \mathrm{U} / \mu \mathrm{L}$ \\
$(8 \mathrm{U} / \mu \mathrm{L})$ & $1 \mu \mathrm{L}$ & $>132 \mathrm{fg}$ per reaction \\
DNA template & To $25 \mu \mathrm{L}$ & - \\
Water & $25 \mu \mathrm{L}$ & \\
Total & $30 \mu \mathrm{L}$ & For prevention of evaporation of \\
\hline Liquid paraffin (Aladdin ${ }^{\circledR}$ Industrial & & water in the reaction mixtures \\
Corporation, Shanghai, China) &
\end{tabular}


Figure S1. A 615-bp DNA sequence from L. biglobosa 'brassicae' for designing of the LAMP primer set. Note the location of the LAMP primer set in the region with nucleotides highlighted in red color. 
Lbb 1 TATAAAGGGTAGTPACAATGAAAACTTAACTTGAGAGCAGCTCATATAAG

Lbc 1 - TAAATGGTGGATAAAATGAGAACTGAACGTGAGAGCAGCTCATATAGA

Lbb 51 TGTTGATTGAGGAA AGTTEATCGAAATAGCAATTATACAGTGCTTPGGT

LbC 49 TGTTGAGTGAGGAGAGTTTGATCGAAATAGCAAATACACAGTGCTTTGGT

Lbb 101 CAGACAATGPAGAAGCTGGCPATGCGAGACAAGCATATGPTPTATTECTT

LbC 99 GAGACAATGTAGCAGGTGGCTATGCGAGACAAGCATATGTTTMACTGCTT

Lbb 151 GCPCPTAGACATGTTCCAGAATGCTGTYCCCGCCPAGACCTGGTAGGCTA

LbC 149 GCTCTTGGAAATATTCCAGAATGCTGTTTCCGCCTAGACCTGGTAGTCTA

Lbb 201 GATTGCPAGGGCCATTGCGATGTGACGCACGCGTPTGGTCAAGCTACCAA
LbC 199 GATTGCTAGGCCGTTGAATGGACGCACATTTGCCAACTACCAA

Lbb 251 GATCGTCGTGAAAGGTTTGPATTGGCCGCGAATTCCGGGTCAAAAGTTGG LbC 249 GATCGTCATGAAAGGGTTGTATCTGGCGCGAGTTCTGGGTTGAAAGTTGG

Lbb 301 TTTGGAAGAGGATACTGGTACAATTCATTTCGGTAGTTTTTTCCAGAAGA LbC 299 TTGGGAAGAGGAGACTGGTACAATTCATTTCGGCGATTTCTTCTMGAA-A

Lbb 351 AAATAGCCATAAAAGAGACGCCGTTMCAATGTAGGAAGTTGAAAAGC LbC 348 AAATAGCCACAAAAGAGGTGCCATTTGCAATGTCAGGAAGTCTGAAAAGC

Lbb 401 TACTGCCTCATGCAACATGGTCGAAAAGTAGATGAAGTCCTGATCAGA LbC 398 TACTGCCTCATGCAAGCCGGTC-AAAAGTAGGATATAGGTCCTGATCAGA

Lbb 451 GAACGTGCAGCCATAGTGGCCAATCTCCAG-CGCTTCGPATTAGGTATGT LbC 447 GAACGTACAGTCATAGTTGCCAATTTCCAGACGCTTCGTATTATGTATGT

Lbb 500 GTECCAATGAAAGTTCCGACATGGACAACACGAACACC TTEATACCAAT LbC 497 GTGCCAATGGAAGTTGCCGACATGTACACCACGAACACGCTGATAGGAAT

Lbb 550 GT-TATTAGCGTCATATCCAATTTAGTGAGCATTCAGTGGGTCTGTTATT LbC 547 ATCTATTAGCGTCATATCCAATTCAGTGAGCATTCAGAGGGTCTGTTATT

Lbb 599 GCGCAGTCTGAAGTTAC

LbC 597 ACGCAGTCTGACGTTAC

Figure S2. Alignment of the 615-bp-long DNA sequence from strain W10 of L. biglobosa 'brassicae' with the corresponding DNA sequence in strain Lb1204 ofL. biglobosa 'canadensis' ( $T$. Luo et al. Huazhong Agricultural University, Wuhan, China, unpublished data). Lbb, L. biglobosa 'brassicae'; Lbc, L. biglobosa 'canadensis'; *, differential nucleotides. 

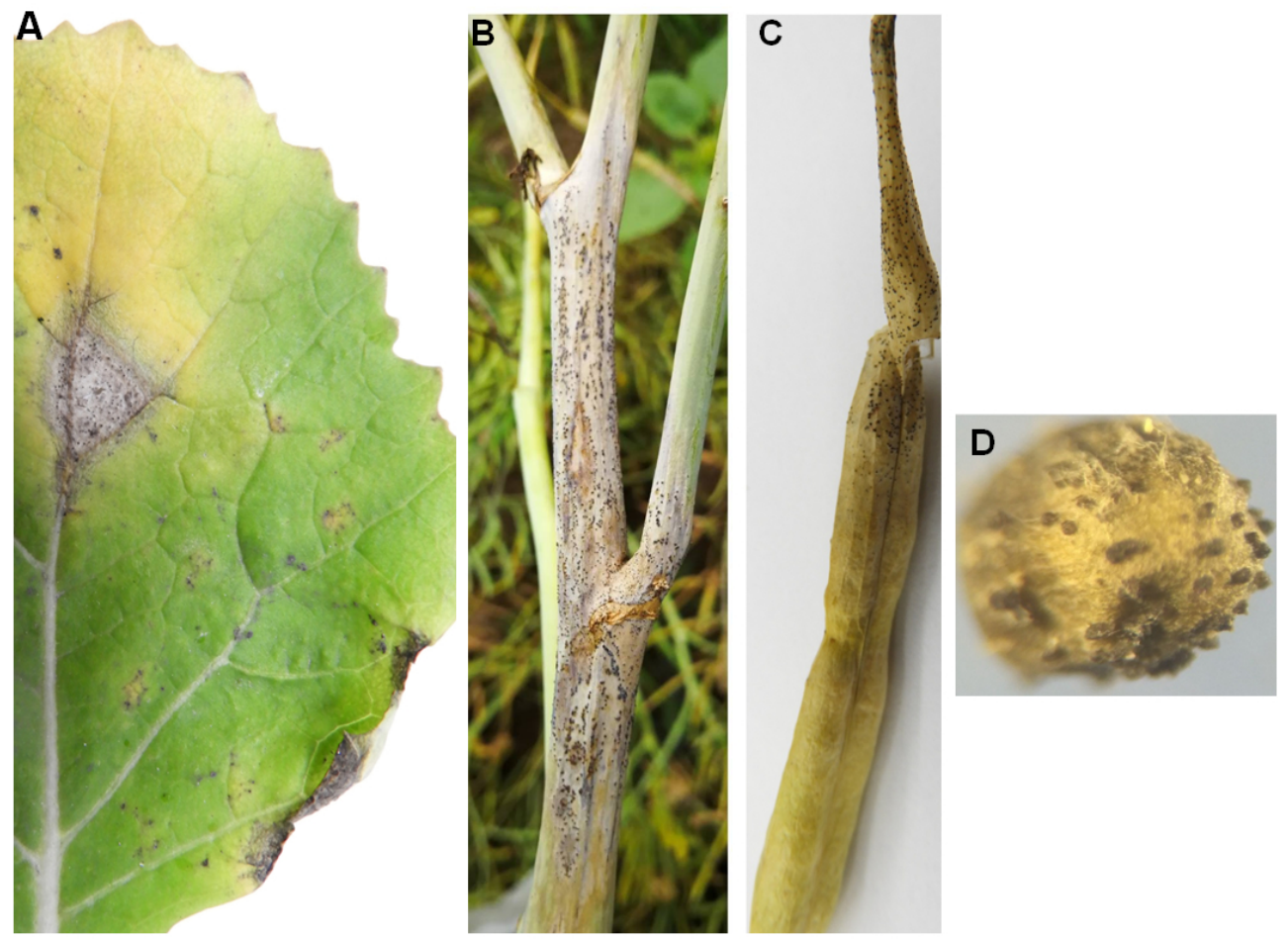

Figure S3. Symptoms of the blackleg disease on a leaf (A), a stem (B), a pod (C) and a seed (D) of oilseed rape (Brassica napus) collected for LAMP diagnosis. Note necrotic plant tissues with formation abundant pycnidia (black dots) on the surface.

$231 \times 169 \mathrm{~mm}(120 \times 120 \mathrm{DPI})$ 